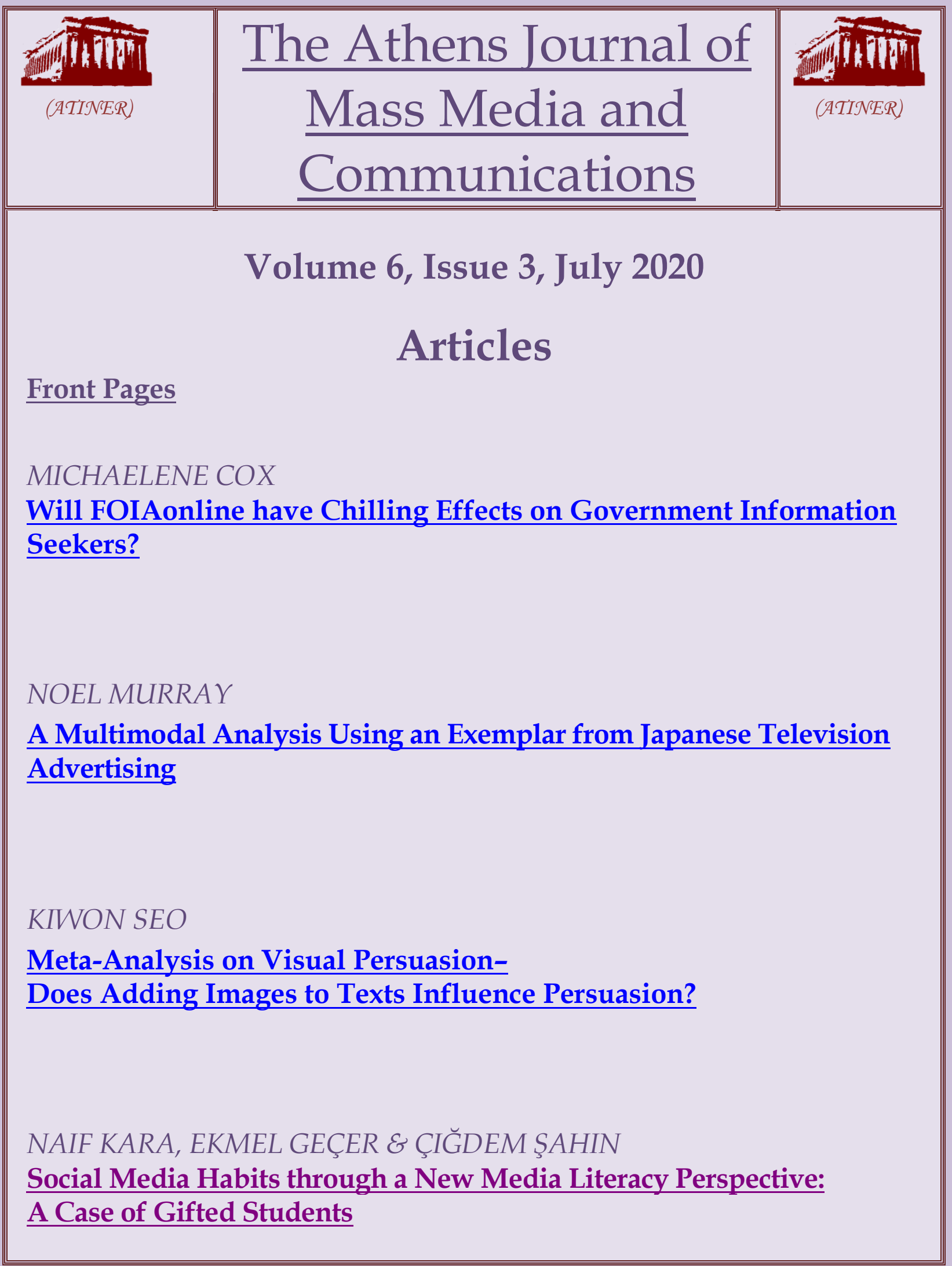




\section{Mission}

ATINER is an Athens-based World Association of Academics and Researchers based in Athens. ATINER is an independent and non-profit Association with a Mission to become a forum where Academics and Researchers from all over the world can meet in Athens, exchange ideas on their research and discuss future developments in their disciplines, as well as engage with professionals from other fields. Athens was chosen because of its long history of academic gatherings, which go back thousands of years to Plato's Academy and Aristotle's Lyceum. Both these historic places are within walking distance from ATINER's downtown offices. Since antiquity, Athens was an open city. In the words of Pericles, Athens"... is open to the world, we never expel a foreigner from learning or seeing". ("Pericles' Funeral Oration", in Thucydides, The History of the Peloponnesian War). It is ATINER's mission to revive the glory of Ancient Athens by inviting the World Academic Community to the city, to learn from each other in an environment of freedom and respect for other people's opinions and beliefs. After all, the free expression of one's opinion formed the basis for the development of democracy, and Athens was its cradle. As it turned out, the Golden Age of Athens was in fact, the Golden Age of the Western Civilization. Education and (Re)searching for the 'truth' are the pillars of any free (democratic) society. This is the reason why Education and Research are the two core words in ATINER's name. 
The Athens Journal of Mass Media and

Communications

ISSN NUMBER: 2407-9677 - DOI: 10.30958/ajmmc

Volume 6, Issue 3, July 2020

Download the entire issue ( $\underline{\mathrm{PDF}})$

$\underline{\text { Front Pages }}$

i-viii

Will FOIAonline have Chilling Effects on Government 147 Information Seekers?

Michaelene Cox

A Multimodal Analysis Using an Exemplar from

161

Japanese Television Advertising

Noel Murray

Meta-Analysis on Visual Persuasion-

Does Adding Images to Texts Influence Persuasion?

Kiwon Seo

Social Media Habits through a New Media Literacy

Perspective: A Case of Gifted Students

Naif Kara, Ekmel Geçer \& Çiğdem Şahin 


\section{The Athens Journal of Mass Media and Communications Editorial and Reviewers' Board}

$\underline{\text { Editors }}$

- Dr. John Pavlik, Head, Mass Media and Communication Unit, ATINER \& Professor, Journalism and Media Studies, School of Communication and Information, Rutgers University, USA.

- Dr. Yorgo Pasadeos, Director, Social Sciences Division, ATINER \& Professor Emeritus, University of Alabama USA.

- Dr. Patrick Vyncke, Professor of Communication Management, Department of Communication Sciences, Ghent University, Belgium.

\section{Editorial Board}

- Dr. John Pavlik, Head, Mass Media and Communication Unit, ATINER \& Professor, Rutgers University, USA.

- Dr. Burak Dogu, Academic Member, ATINER \& Vice Dean, Izmir University of Economics, Turkey.

- Dr. Andzela Armoniene, Head of The Fund Young Researcher, Lithuania.

- Dr. Mariam Gersamia, Professor \& Head, Division of Journalism and Mass Communication, Ivane Javakhishvili Tbilisi State University, Georgia.

- Dr. Egle Jaskuniene, Associate Professor \& Vice Dean for Research, Faculty of Creative Industries, Vilnius Gediminas Technical University, Lithuania.

- Dr. Berrin Yanikkaya, Academic Member, ATINER and Professor \& Head, School of Communication Studies, Auckland University of Technology, New Zealand.

- Dr. Dali Osepashvili, Professor, Department of Journalism and Mass Communication, Ivane Javakhishvili Tbilisi State University, Georgia.

- Dr. Walter Wymer, Academic Member, ATINER \& Professor of Marketing, University of Lethbridge, Canada.

- Dr. Alan Albarran, Academic Member, ATINER \& Professor, The University of North Texas, USA.

- Dr. Patricia L. Dooley, Elliott Distinguished Professor of Communication, Wichita State University, USA.

- Dr. Catherine Ann Collins, Professor, Department of Rhetoric, Willamette University, USA.

- Dr. Pamela Doyle Tran, Professor of Electronic News, University of Alabama, USA.

- Dr. S. Andrews, Professor, Department of Information Technology, Mahendra Engineering College, India.

- Dr. Emmanuel Ngwainmbi, Department of Communication Studies, The University of North Carolina, USA.

- Dr. Zsolt Alfred Polgar, Academic Member, ATINER \& Associate Professor, 
Technical University of Cluj-Napoca, Romania.

- Dr. Margaret M. Cassidy, Academic Member, ATINER \& Associate Professor, Adelphi University, USA.

- Dr. Baris Coban, Associate Professor, Communication Sciences Department, Dogus University, Turkey.

- Dr. Ulas Basar Gezgin, Associate Professor of Applied Communication, British University Vietnam, Vietnam.

- Dr. Anya Luscombe, Associate Professor and Head, Department of Academic Core, University College Roosevelt, The Netherlands.

- Dr. Charles Obot, Academic Member, ATINER \& Associate Professor, University of Uyo, Nigeria.

- Dr. Ceren Sozeri, Associate Professor, Faculty of Communication, Galatasaray University, Turkey.

- Dr. Matthew D. Matsaganis, Assistant Professor, Department of Communication, State University of New York (SUNY), USA.

- Dr. Geneviève A. Bonin, Assistant Professor, University of Ottawa, Canada.

- Dr. Klarissa Lueg, Assistant Professor, Aarhus University, Denmark.

- Dr. George Pavlou, Assistant Professor, European University, Cyprus.

- Dr. Yolandi Slabbert, Senior Lecturer, Department of Communication Science, University of South Africa, South Africa.

- Dr. Daniel Binns, Academic Member, ATINER \& Lecturer, RMIT University, Australia.

- Dr. Binoy Kampmark, Lecturer in Social Sciences, School of Global, Urban and Social Studies, RMIT University, Australia.

- Dr. Sarah Sparke, Academic Member, ATINER \& Research Associate, CMIR, University of the West of England, UK.

- Dr. Vittoria Sacco, Postdoctoral Assistant, Neuchatel University, Switzerland.

- Ms. Mania Alehpour, PhD Candidate, University of Tehran, Iran.

- General Managing Editor of all ATINER's Publications: Ms. Afrodete Papanikou

- ICT Managing Editor of all ATINER's Publications: Mr. Kostas Spyropoulos

- Managing Editor of this Journal: Ms. Zoi Charalampous (bio)

\section{Reviewers' Board}

Click Here 


\section{President's Message}

All ATINER's publications including its e-journals are open access without any costs (submission, processing, publishing, open access paid by authors, open access paid by readers etc.) and is independent of presentations at any of the many small events (conferences, symposiums, forums, colloquiums, courses, roundtable discussions) organized by ATINER throughout the year and entail significant costs of participating. The intellectual property rights of the submitting papers remain with the author. Before you submit, please make sure your paper meets the basic academic standards, which includes proper English. Some articles will be selected from the numerous papers that have been presented at the various annual international academic conferences organized by the different divisions and units of the Athens Institute for Education and Research. The plethora of papers presented every year will enable the editorial board of each journal to select the best, and in so doing produce a top-quality academic journal. In addition to papers presented, ATINER will encourage the independent submission of papers to be evaluated for publication.

The current issue is the third of the sixth volume of the Athens Journal of Mass Media and Communications (AJMMC), published by the Mass Media \& Communication Unit of ATINER

Gregory T. Papanikos

President

ATINER 


\section{Athens Institute for Education and Research}

\section{A World Association of Academics and Researchers}

19th Annual International Conference on Communication and Mass Media, 10-13 May 2020, Athens, Greece

The Mass Media \& Communication Unit of ATINER organizes its 19th Annual International Conference on Communication and Mass Media, 10-13 May 2021, Athens, Greece sponsored by the Athens Journal of Mass Media and Communications. The aim of the conference is to bring together academics and researchers of Communications, Mass Media and other related disciplines. Please submit a proposal using the form available (https://www.atiner.gr/2021/FORM-MED.doc).

- Abstract Submission: 12 October 2020

- Acceptance of Abstract: 4 Weeks after Submission

- Submission of Paper: 12 April 2021

\section{Academic Members Responsible for the Conference}

- Dr. John Pavlik, Head, Mass Media and Communication Research Unit, ATINER \& Professor, Rutgers University, USA.

- Dr. Yorgo Pasadeos, Director, Social Sciences Division, ATINER \& Professor Emeritus, University of Alabama USA.

\section{Social and Educational Program}

The Social Program Emphasizes the Educational Aspect of the Academic Meetings of Atiner.

- Greek Night Entertainment (This is the official dinner of the conference)

- Athens Sightseeing: Old and New-An Educational Urban Walk

- Social Dinner

- Mycenae Visit

- Exploration of the Aegean Islands

- Delphi Visit

- Ancient Corinth and Cape Sounion

\section{Conference Fees}

Conference fees vary from $400 €$ to $2000 €$

Details can be found at: https://www.atiner.gr/2019fees 


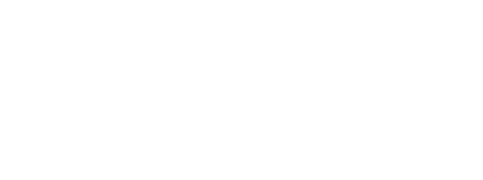




\title{
Will FOIAonline have Chilling Effects on Government Information Seekers?
}

\author{
By Michaelene Cox*
}

\begin{abstract}
This study examines an online pilot program introduced by the US federal government in 2012 to help fulfill mandates of the Freedom of Information Act. The FOIAonline program has not been subject yet to academic scrutiny. The study herein aims to initiate discussion about anticipated and unforeseen legal and political implications of FOIAonline, particularly in regard to user privacy. This preliminary examination serves to encourage further dialogue about the merits of some government online services, and in doing so contributes to a growing body of knowledge about institutional cynicism. The qualitative case study draws on the theoretical lens of threat avoidance to explain why public demands for government transparency can be accompanied by unintended corollaries. FOIAonline is a double-edged sword in which access to information is an essential defense of democracy and at the same time can wield threats to individual rights. The paper illustrates that privacy rights of government information seekers are increasingly compromised by unrestricted access to online FOIA requests and responses. Public scrutiny of individuals and groups who request government files will likely continue to discourage participation in the e-government program. However, FOIAonline can gain added value for agencies and requesters alike by minimizing anxieties of government information seekers. In an effort to further streamline government services, architects of the FOIAonline program hope to increase voluntary participation of US federal agencies; further, the program is being considered as a model for adoption by other country governments. This study has implications for both domestic and international governing bodies by offering practitioners insight into the challenges of refining and expanding the pilot program.
\end{abstract}

Keywords: Transparency, Privacy, Trust, Freedom of Information, FOIAonline.

\section{Introduction}

Desire for transparency in government is longstanding. As early as fifth century BC, for instance, Athenians cultivated an informed citizenry by chiseling fiscal accounts of their city-state in stone and placing them in public spaces (Irwin, 2013). By the twentieth century, evolution in the storage and delivery of government agency information - massive amounts of it — had evolved to paper, tapes and film and along with it, legislation in many countries authorizing release of those records. Open government initiatives and an "information-savvy public" have now exponentially increased demand for government-held information (Dillow, 2016). As a result, manual processing of requests has weighed heavily on agency costs and capabilities. More recently, some US legislative reforms have broadened the scope of what defines public records to include emails, text messages, online data storage and other digital formats, and correspondingly, the means by which the public can request and receive government information. Access laws are as crucial to fostering government transparency as new technologies. A recent web-based

\footnotetext{
*Associate Professor, Illinois State University, USA.
} 
US federal pilot program serves to illustrate the next evolutionary step in government transparency. The FOIAonline project has capacity to facilitate requests for information and documents made to more than 100 federal agencies authorized to respond to FOIA requests, with an eye to lowering costs, simplifying the request process, and improving efficiency through optimizing shared services, standardization, and electronic management of data. Yet at the same time, any computer user can find names and personal information about individuals or groups who request government information through this program.

Thus, there persists a tension between democratic ideals of the public-right-toknow and basic rights of individual privacy. The purpose of this case study is to examine one manifestation of that tension and is three-fold. First, it will introduce the reader to a web-based US federal government service initiated as a pilot program in Fall 2012 called FOIAonline. The paper will track its legislative lineage from the Freedom of Information Act (1966), and its subsequent amendments, to a bill currently before Congress called The FOIA Oversight and Implementation Act. The introduction will also include organizational aspects, operational processes, and perceived benefits of the digital service. In addition to requesting information from government agencies, for instance, users can also find information about other individuals or groups requesting government information. This novel feature is one which provides impetus for the paper at hand. Thus, the second purpose of this study is to review and synthesize relevant research about the relationship(s) of e-government services, perceived transparency in government, public trust, and user privacy. Finally, and more importantly, the paper aims to initiate discussion about both the anticipated and unforeseen legal and political implications of FOIAonline, particularly in regard to user privacy.

\section{Literature Review}

Harnessing new technologies to widely publish data is irresistible in an era of open government initiatives. The hope is that by doing so, governments will facilitate democratic goals as well as enhance interagency cooperation, streamline administrative responsibilities and reduce costs, among other things. It seems a foregone conclusion. An overview in this paper of the recent FOIAonline pilot program in the US illustrates an assumption lurking behind that promise. Policymakers believe that by offering a consolidated nationwide portal for requesting and retrieving government records, it will be widely used by both the public and government agencies. But will it? One of the challenges facing meaningful assessment of such projects is lack of consensus on quality measurement frameworks. There are a considerable number of studies about predictors of successful open data initiatives, and they provide mixed findings. For instance, the key may rest with one or more variables such as stakeholder(s) power and interests (Zuiderwijk et al., 2015), political structure and processes (Gulati et al., 2014), technology acceptance (Mardiana et al., 2015), and socio-demographic and economic factors (Chan, 2013; Taipale, 2013). Likewise, barriers to full realization of government open data may hinge on conflicting regulations, liability 
of data providers, and privacy and data protection (Attard et al., 2015).

The right to privacy can be at odds with the goals for open government data, and more research is needed on this matter (Attard et al., 2015). Rony (2012) argues that while there is much attention paid to issues of transparency and openness in e-participation initiatives, there is a dearth of studies which focus on policy and legal matters. Privacy issues would appear to be at the forefront of those policy and legal concerns. Thus rethinking the value and risks of FOIAonline is paramount to understanding its usage. There is growing scholarly interest in explaining low utilization of government websites, a phenomenon not anticipated when open data technologies were first introduced. User perspectives such as perceived risks are found to be correlated with usage (Carter and Belanger, 2005; Patel and Jacobson, 2008). Although it does not directly address freedom of information requests, one recent study finds that trust in both the Internet and in the government are determining factors that attract or dissuade users of egovernment services (Mpinganjira, 2015). An examination of the effect of The Freedom of Information Act 2000 in the United Kingdom reveals that while the Act enhanced perceptions of government accountability, it did not significantly improve trust in government (Worthy, 2010). Further, it is argued that public trust is low in large part because of negative media reports, not degree of ease in accessing government information. In fact, the general public rarely makes use of FOI rights and that in the UK it "only works if almost no one uses it" (Shepherd, 2015). The explanation offered is that current request levels from activists and professionals alone already test government's ability to timely respond. To improve FOI services online would require data being integrated from different sources for interconnectedness which then raises concerns about privacy. We can apply that argument to the US FOIAonline which does indeed link agency data and so cannot provide complete anonymity to users.

\section{Context}

This paper hypothesizes that users of FOIAonline will find the benefits of requesting and retrieving government information and documents online compromised by the prospect of having personal information openly available to the public, and thus usage of the program will be stymied. This is consistent with a review of scholarly literature about the relationship between public trust and eparticipation. To stimulate informed debate about the concern, background information about the project through summation of government reports and legislation, and an examination of the online program itself is offered. The case study offers qualitative analysis through the theoretical lens of threat avoidance to explain why public demands for government transparency can be accompanied by unintended corollaries. Participation in the pilot program can compromise privacy of government information seekers by freely disclosing user personal information and motives online to the general public, and thus serve as an unwelcomed price for individuals requesting government documents electronically. On the other hand, public disclosure of information about requesters might arguably be 
regarded as a public good. Anyone with access to the Internet can learn who requested what, and in some cases why, and can peruse the same records received by the initial requester. Seeking transparency in government appears to require a willingness to accept transparency of the self.

\title{
US Freedom of Information Act (FOIA)
}

In the early years of the new Republic, the fourth president of the United States wrote to a fellow statesman expressing mutual support for public schools and libraries. While James Madison had long been a proponent for developing an informed citizenry in democratic governance his words are frequently misquoted now in context of publicly disclosing information and documents controlled by the government. Madison wrote:

\begin{abstract}
"A popular government, without popular information, or the means of acquiring it, is but a Prologue to a Farce or a Tragedy -- or perhaps both. Knowledge will forever govern ignorance, and a people who mean to be their own Governors must arm themselves with the power which knowledge gives" (Madison, 1822).
\end{abstract}

The quote made its way into a 1966 US Senate Judiciary Committee report which advocated passage of the country's original Freedom of Information Act (FOIA). The law went into effect the following year and Madison has since been credited as its philosophical father. In spirit, his words do indeed reinforce basic principles of democracy including government accountability, transparency, control of the abuse of power and citizen participation, all of which require knowledge.

The notion of legislating access to information and documents as a means to facilitate transparency in government and to foster an informed citizenry was not new when the US deliberated upon its FOIA - Sweden passed a rudimentary form of the act in 1766 and Finland enacted an information law in 1951-but the US was the first to throw open the door to a wide array of federal agency materials under the legal presumption of the "right-to-know" principle. A wave of democratic transitions in the latter twentieth century and pressures for open governance has since expanded adoption of FOI laws by about 100 countries to date. The status of FOI laws and their compliance varies around the world considerably in respect to quality and strength but suggest international support for transparency and public right-to-know principles. No statutory right for access to government-held information is absolute, of course. In the US, with fairly standard exceptions regarding issues of sensitivity and personal rights, requests from the public are nevertheless expected to be granted without cost or at minimal cost, and with the burden of proof falling on the government body rather than on the requester. That is, individuals and organizations seeking government-held records generally are not required to explain their reasons for wanting the information or documents, while agencies must provide convincing arguments to withhold disclosure on grounds that they view particular requests as falling under the rubric of one or more permitted exemptions.

Prior to the FOIA, US government agencies were given much latitude as to 
what information, if any, they might choose to share with the public. Agencies could respond to government-information seekers with subjective standards that agency administrators conjured for the occasion. There was no enforceable legal right for public inspection. President Lyndon Johnson reversed earlier legislation that had provided minimal oversight of federal agencies regarding the matter by signing the first FOIA bill in 1967. He declared that, "No one should be able to pull the curtains of secrecy around decisions which can be revealed without injury to the public interest" (US Senate, 1974, 1). The Act was almost immediately replaced with another and similar one, and then reflecting changing political climates over the next few decades, was amended multiple times to alternately strengthen transparency or to limit FOIA protections. Numerous reiterations of the law and needed clarification of disclosure exemptions now challenge both requesters and agency administrators (US Senate, 2015, 3). To serve as a resource for government information seekers and agencies, and as an ombudsman in requester-agency FOIA disputes, the Office of Government Information Services (OGIS) was created by Congress in 2007 under the Open Government Act. There are currently nine categories of information that give agencies discretion in determining if the risks of disclosure outweigh right-to-know principles. The Department of Justice lists these statutory exemptions for information that is: (1) classified to protect national security, (2) solely related to agency internal personnel rules and practices, (3) prohibited by another federal law, (4) confidential and privileged commercial or financial information such as trade secrets, (5) privileged inter-agency communications such as attorney-client privileges, (6) invasion of individual personal privacy such as medical files, (7) compiled for law enforcement purposes under certain conditions, (8) related to regulation of financial institutions, and (9) geological information about wells. Refusals to disclose information that do not clearly fall under these exclusions leave the government vulnerable to law suits, with court decisions generally favoring disclosure if there is doubt that the requests are protected under FOIA. This paper is concerned about the impact that recent amendments and a bill currently before Congress has on one of the exemptions - invasion of individual personal privacy. New technologies make it even more difficult to strike a proper balance between transparency in government and reasonable exemptions.

With introduction of the World Wide Web in 1991 and swift development of the Internet, the federal government lost little time in bringing the FOIA into the digital age. Passage of the 1996 Electronic Freedom of Information Act Amendments (E-FOIA) was its first move to expand the scope of government record storage and retrieval processes in electronic format. The subsequent E-Government Act of 2002 fine-tuned management of e-services to increase efficiency and effectiveness in providing access to agency information. One of the most significant requirements of the Act is that all federal agencies must create electronic reading rooms for public access to information and documents generated after 1996 and covered by FOIA. At the same time, agencies receive guidance on developing minimum information security standards, particularly in regard to protecting personally identifiable information, although conformance on policies and procedures varies among agencies (GAO, 2008). Other manifestations of the FOIA took shape in 
light of e-government initiatives, most notably a nationwide FOI portal.

\section{FOIAonline}

The US was not the first to launch a consolidated government portal, however. A decade earlier, the Mexican government published a website to electronically process information requests at the national and state level that became a model for single-entry portal (SEP) in FOI matters (The Canadian Press, 2012). The US FOIAonline platform was unveiled in 2012. Like many such initiatives to move services online, the SEP was designed to increase efficiency and lower costs in processing public requests for agency information and documents, standardize quality and quantity of those goods, and reduce overlaps between individual agency website reading rooms. Less than a year after FOIAonline was in place, President Obama signed the Open Data Executive Order which made the default for newly generated government records be provided in free and digital format.

The need to move from manual to electronic processing of FOIA requests was critical and as noted above, federal mandates required agencies to make data assessable for public inspection. Agencies complied through their own websites, albeit with varying degree of content and usability. A government summary report provides history on FOIA electronic requests over the past few years. In 2012 when FOIAonline was implemented as a pilot program, the federal government and its approximate 100 agencies subject to FOIA had received a total of about 650,000 public requests for information. The agency with the highest number of requests was, and still is, the Department of Homeland Security. Together with the Departments of Justice, Defense, Health and Human Services, and Veteran Affairs, the five agencies receive nearly 70 percent of all FOIA requests. The average processing time in 2012 for simple requests was just over 20 days, with a fulltime FOIA staff of about 4,300. In 2014 there were nearly 715,000 FOIA requests but about 30,000 fewer processed than the year before. Processing time was only minimally improved. Staffing was at its lowest with about 3,800 fulltime employees, yet at the same time, total estimated costs for 2014 FOIA activities was at its highest at $\$ 462$ million dollars. The summary report attributes a slight increase in costs of processing and agency appeals, and to a "multitude of additional challenges...during these tough fiscal times" (US Department of Justice, 2015). Given that FOIAonline had been live for only two years and includes only a handful of agencies, we should not expect to have seen immediate improvements in efficiency and costs. But the report makes clear a mounting public demand for government information, an increase in backlog of agency responses, and therefore impetus to expand the online pilot program.

A bill currently before Congress seeks to clarify some of the language in the recently passed FOIA Improvement Act of 2015. The FOIA Improvement Act reinforces agency rights to maintain their own websites to receive and process requests but speaks to advantages of participating in the consolidated FOIAonline program. It mandates that "proactive" disclosure of public interest be made electronically. Further, it reminds agencies that a "presumption of openness" applies. In support of the Act, President Obama admonished agencies against 
withholding records "merely because public officials might be embarrassed by disclosure, because errors and failures might be revealed, or because of speculative or abstract fears" (US Senate, 2015).

There are currently a dozen agencies participating in FOIAonline with some having only a certain portion of the agency involved: Department of Commerce, Department of Justice (only its Office of Information Policy), Department of the Navy, Environmental Protection Agency, Federal Communication Commission, Federal Labor Relations Authority, General Services Administration, Merit Systems Protection Board, Pension Benefit Guaranty Corporation, National Archives and Records Administration, Small Business Administration, and US Customs and Border Protection. We can immediately see why efficiency and costs in processing FOIA requests has not yet been mitigated by the SEP-with the exception of one office of the Department of Justice, none of the five agencies which annually draw the most requests are participating in the pilot program. At this time, agencies are not mandated to participate in nationwide program, and those that do may participate for a limited period of time. This was the case of the US Citizenship and Immigration Services agency that used FOIAonline for certain requests and then withdrew from the program within a year. Federal or agency assessments are not available yet, although some nongovernmental organizations have reviewed the program. The driving forces originally behind FOIAonline were the Environmental Protection Agency and the Department of Commerce which fronted most of the $\$ 1.3$ million cost to launch the program, and which anticipate a savings of $\$ 200$ million to the federal government in the first five years of its implementation if widely adopted. By 2014, more than 170,000 requesters had registered as users and participating agencies had processed more than 200,000 FOIA requests and put about 400,000 records online (Mitchell, 2014).

One of the preeminent features of FOIAonline is that it provides one-stop shopping for government information seekers and so is particularly useful if multiple agency data is required. Instead of sending requests to individual agencies and waiting for agency administrators to respond, the user can submit a request for information or records through the national SEP. Users need not register to file a request, but the simple and free registration offers more features to the public such as tracking and communication capabilities. The program allows users to track progress of their request, communicate directly with agency personnel processing the request and if necessary electronically file appeals with agencies if responses are not forthcoming. The FOIAonline search engine allows anyone with access to the Internet to search requests made by other individuals or groups, including name of requester, mailing address and date and in some cases the reason for requesting the specific request. Users can also access documents already released to FOIA requesters if the agency permits, and can generate reports from stored data. The site provides user training, and information about relevant federal statutes such as The Privacy Act of 1974. There are also benefits to participating agencies. The automation of FOIA processing offers agencies a secure central repository to store requests and post responses. Having requesters go to a single portal, instead of an agency site, reduces agency overlap and cost in processing and responding. The new system offers agencies search features to generate internal 
management reports as well as to file required annual reports to the federal government. The open access platform appears attractive on all accounts. However, the concern raised in this paper regards user privacy. To submit a FOIAonline request, at minimum the user name and mailing address must be provided. If the user is seeking information on behalf of a group, the group information is included as well. If the requester adds notes or instructions, that is included verbatim. Once a request is entered, a tracking number is assigned, the name of the agency which is responsible for processing the request is provided, and the disposition of the request is listed, such as if an appeal has been filed. This data is available to anyone accessing the program. The FOIAonline site explains to users that while The Privacy Act of 1974 protects personal information collected and stored by the system to some degree it does not cover all information collected online and may be shared with any government agency, the general public and/or third party websites. Agencies can use Google Analytics to track summary information about site usage through cookies including the user domain name and internet address, type of browser and operating system used, pages viewed and length of time spent on each page, route taken to access the website, and connection speed of the session.

The value of FOIAonline can be properly assessed after the system has been in place a bit longer. In the meanwhile, we can note some drawbacks. The most apparent limitation is the lack of agency participation, particularly from those agencies receiving the most requests for records. With nearly all federal agencies maintaining their own websites for electronic requests and responses, interest in consolidating services appears lackluster. One investigation conducted of federal agency websites to determine compliance with the 1996 Electronic Freedom of Information Act found that even agency online reading rooms suffer. Many links to content are broken or removed, content is not regularly monitored for accuracy, and there is no consistency in the nature and amount of information made available on their sites (Gordon-Murnane, 1999). Replicating that study six years later, other researchers found significant improvement and claim that 88 percent of federal agencies provide "clear and distinct" access to their FOIA pages (Oltmann et. al., 2006). Nevertheless, an increase in agency backlogs in fulfilling requests and a rise in requester-agency disputes, lead some observers to worry about the overuse of FOIA exemptions to withhold records from disclosure. Particular to FOIAonline, data available for user request only goes back to 2012 when the website was introduced, although agencies have been encouraged to download more to the central repository. It may be more practical after all for users to simply go to an agency website where more electronic data might be available. Thus FOIAonline search functionality is limited. A nongovernmental organization called OpenTheGovernment.ORG: Americans for Less Secrecy, More Democracy (ORG) provides a score card on the new program. Praise goes for the ease with which users can make requests online and for a feature which provides users an estimated response date. But low marks are given to the frequency with which agencies do not meet the mandated 20 day working deadline, and the lack of updates to the user about delayed processing time. Further criticism noted continued failure of agencies to file documents to the online repository (ORG, 
2013). Most observers would agree that ready access to government records should foster transparency and democratic goals. But as research in e-government reveals, simply offering online services and posting information assumes and cannot assure that more citizens will make greater use of the new technology. Furthermore, requesting FOIA information online entails making user personal information public. Any transparency gained by FOIAonline goes both ways.

\section{Discussion}

The literature indicates room to further explore the relationship between egovernment services and user trust as it is related to privacy issues. The US model examined here reveals advances and challenges in opening governmental digital databases for public access. Although it has been less than a decade since the FOIAonline project was introduced, lessons learned already during that short period in obtaining legislative guidance, interagency cooperation, technological infrastructure, and providing public awareness have significant implications for transnational organizations and other governments. Democratic governing bodies across the globe that are agreeable to building greater trust among their citizens by cultivating a more transparent and participatory civic environment might look to the US experience to tailor their own information systems. This includes treading carefully where FOIAonline has faltered.

For instance, status reports indicate that to date the FOIAonline pilot project has not performed as well as its architects likely anticipated. This can be explained in part by inadequate agency participation and by relatively low usage by requesters. Explanations for reticent agency participation are not articulated in assessments of the program but we can posit several possible factors based on organizational theories. Agencies required to provide electronic information and documentation have already integrated a request/response reading room and repository of records on their own websites. Beyond statutory requirements, the federal government grants agencies considerable latitude in the administration of FOIA. Thus there is little incentive for them to merge databases and process requests in standard fashion. Silos of information are the norm; agency competition and sense of independence are notoriously averse to interagency coordination. Also to consider is the novelty of FOIAonline. Agencies are notoriously resistant to change - in other words, risk adverse. As for government information seekers, most requests are currently filed with individual agencies rather than through the consolidated online program, surely in large part because there is little agency representation in FOIAonline. It appears to be the classic chicken or the egg causality dilemma.

However, if we imagine a future in which the program successfully integrates all or most agency request-response databases, the dilemma still may not be resolved. Presumably a consolidated program will pull users away from individual agency sites, which by the way, do not have the same tracking or search engines employed by FOIAonline. As a result, users will find their personal information included in a growing database and available for domestic and international public 
perusal. Seeking government information requires disclosure on both ends. After all, requests will not be processed without providing and publishing minimal information about the requester. That information will be widely available to any government agency and to anyone in the public sphere with access to the Internet. One can imagine the usefulness of requester data to marketers, employers, neighbors, activists and a host of others including those with nefarious objectives. It is alarming to consider that the ease with which personal information of requesters can be obtained domestically and internationally through this system may threaten the safety, reputation, finances and other measures of well-being to information seekers. Potential misuse of any FOIAonline service is one more phenomenon not easily checked within the border of any country. Thus, greater visibility may increase requester anxiety about privacy issues and erode trust in government transactions. Subsequently we would expect to find citizens less willing to participate in the e-government service.

In regard to trust, here we find room to predict continued low use of FOIAonline by drawing on well-accepted and related behavioral theories. Protection motivation theory, or risk aversion, can explain why some users are especially sensitive to the degree to which online security is provided —or at least their perception of online security. The element of trust is a fundamental component of legislation protecting privacy of individuals. FOIAonline is not the only government e-service program that requires the consumer to divulge personal information but is one which freely opens that collected information to the public, some of which may be of a sensitive nature. A multitude of search terms in the program can be employed to locate data. The case study here draws upon a deliberate or purposive sampling method to collect data that illustrates privacy issues in stake. It searches the first two years that FOIAonline was in operation and selects two records that include similar and different pieces of personal data. Both clearly identify the individuals asking for government information and the nature of their requests. This alone may not be troublesome. However, these two samples also reveal startling revelations directly related to the requesters that may provide fodder for mischievous others browsing the database, or at the very least, reveal matters that the requesters prefer to remain private. Consider some of the information found in these two samples:

\footnotetext{
A FOIAonline request to the US Department of Commerce was filed by Katie Draphcho on behalf of the Democratic Senatorial Campaign Committee in February 2013 asking for an agency log or report/index i.e., web flow with entries of correspondence. One of the documents released included recorded Aspen, Colorado discussions on an Arctic science agreement.

In another case, a FOIAonline request filed in January 2014 to the Environmental Protection Agency by Kristine Savona stated: We would like to request any information your office has regarding any environmental documents, underground storage tanks (USTs) or hazardous materials for the property listed below. If any records are located, we would like to obtain copies or schedule a file review. If no records are available, please contact me to confirm. Thank you for your assistance. 460 New Mexico 528, Bernalillo, NM 87004.
} 
As noted above, the implications of publishing user requests such as these may violate privacy laws and potentially cause harm. One can reasonably assume that Ms. Draphcho is a Democrat and looking for political communications about particular and possibly controversial issues that may be useful to her party. This might be helpful information for Republican candidates to have in the race too, but more importantly, the FOIAonline request publicly identifies party affiliation and political activities of an individual. The second case also opens an individual's request for particular government information to public scrutiny. We do not know if Ms. Savona rents or owns the property in question, but we do know she receives mail at that address and has concerns about potential environmental hazards. This information is now available to family members, neighbors, lawyers, activists, marketers, real estate agents, and anyone else with access to the Internet. Portions above from the two sample reports represent critical cases, pointing to significant features frequently found in other requests. The reports are brief and allow ease in categorizing and analyzing profile data that directly address the purpose of this study. The value of deliberate sampling such as this is when critical cases demonstrate that "if it happens there, it will happen anywhere," and that while broad generalizations may not be possible, studying a few instances permits us to make logical generalizations (Patton, 1990, 174-175). Overall, there is usefulness in this single case study about the US FOIAonline program itself. It raises the specter of potential assaults to privacy rights of government information seekers around the world. After all, "if that group is having problems, then we can be sure all the groups are having problems" (Patton, 1990, 175).

Because FOIAonline is new and thus far attracts relatively few requesters, there is still little public awareness about wide accessibility to its database - or even awareness by requesters about the implications of seeking government information in this manner. Speaking about companies that engage in transactions online, one observer notes that "though consumers worry about how their personal data is gathered and used, they're surprisingly ignorant of what data they reveal when they're online, and most companies opt not to enlighten them, and this dynamic erodes trust in firms and customers' willingness to share information" (Morey et al., 2015). We understand similar anxieties can be experienced by consumers of government e-services. The public is savvy enough by now to realize a user may likely lose anonymity to government administrators in exchange for a good. However, benefit and cost calculations assume a different intensity if a user learns that personal information is publicly disclosed. When information under FOI was manually requested and manually processed with documents mailed to their homes, requesters had only to weigh perceived benefits of receiving information against risks of government scrutiny. Today, the mere linking of one's name and mailing address to a request for particular records can produce heightened anxiety for government-information seekers in any country. In addition to gauging the level of trust they have with government, requesters must now weigh how trusting they are of the general public. There are very few empirical studies examining the impact of trust on usage of government services for obtaining information, and none specifically examining the public disclosure feature of FOIAonline. Threat avoidance theory helps to explain why privacy 
concerns are major challenges for public acceptance of e-government services, and is frequently discussed in the same breath as cost-and-benefit models to explain low e-government usage (Alqahtani and Lu, 2015; Liang and Xue, 2009). The concept of threat avoidance is also subsumed under an extended social cognitive theory (SCT). Although SCT per se has not widely been employed in studies of egovernment, several factors are shown to influence usage of computer systems and other new technologies including expectations of outcomes, self-efficacy, behavioral intentions, and anxiety (Rana and Dwivedi, 2015). In short, levels of anxiety heightened by distrust can lead to risk aversion. It is not a far reach to predict that FOAIonline will have a chilling effect on the willingness of citizens to electronically request government records.

\section{Conclusion}

Freedom of information laws promise to contribute to better governance by teaming public officials and citizens in an effort to produce greater transparency and accountability in government decision making. As noted earlier, however, there is a delicate balance between democratic ideals of public-right-to-know and basic rights of individual privacy. This paper invites examination of anticipated and unforeseen legal and political implications of FOIAonline, particularly in regard to user privacy. As open government initiatives snowball, they increasingly draw attention from researchers trying to measure the extent to which FOI statutes have been successful. One major criticism of US FOI laws is that a long list of exemptions and lingering discretion by public officials to release information appears to be a persistent obstacle. This defies adequate assessment of FOI. There are neither national standards embedded in US common law nor international standards (Hughes, 2014). Such lack of international standards especially has significant import for governments planning to provide similar online information services.

This paper proposes that another obstacle rests with the newly introduced FOIAonline program. While open government is widely regarded as a human right, so is right to privacy. The evolution of FOIA reminds us of the political goals and legal developments that the US federal government has steered for the past 50 years, and that other countries aim to emulate. A presumption of openness and principles of right-to-know undergird the project. The pilot program and its outcomes have not been scrutinized carefully, and yet are being considered by other countries such as Brazil and Canada as a possible model for open government reform efforts. This paper suggests that the program will gain added value for both agencies and requesters if anxieties of government information seekers is purposely minimized. This might be accomplished by appropriately educating requesters about potential risks of being included in a publicly available database, and even more effectively, by giving control of personal information, such as name and mailing address, to those requesters desiring anonymity. As is, the FOIAonline program that some US federal agencies have adopted may indeed have chilling effects on government information seekers and thus points to a double-edged sword of transparency. 


\section{References}

Alqahtani, A. and Lu, H. 2015. Sensitivity Level-Based Citizen Personal Information Model for Privacy Protection. Journal of Software. 10, 1, 42-55.

Attard, J., Orlandi, F., Scerri, S., and Auer, S. 2015. A Systematic Review of Open Government Data Initiatives. Government Information Quarterly. 31, 4, 399-418.

Canadian Press (7 October 2012), "Access-to-information requests to go online." [online] http://www.cbc.ca/news/politics/access-to-information-requests-to-go-online-1.1166 317

Carter, L. and Belanger, F. 2005). The Utilization of e-Government Services: Citizen Trust, Innovation and Acceptance Factors. Information Systems Journal. 15, 1, 5-25.

Chan, C. 2013. From Open Data to Open Innovation Strategies: Creating e-Services Using Open Government Data. $47^{\text {th }}$ Hawaii International Conference on System Sciences, 1890-1899.

Dillow, C. 2016. The Role of Automation in FOIA Compliance. Information Management Journal. 50, 1, 37-39.

Gordon-Murnae, L. 1999. The Electronic Freedom of Information Act: The Promise Remains Unfulfilled. Searcher. 7, 4, 40-51.

Gulati, G., Williams, C. and Yates, D. 2014. Predictors of On-Line Services and eParticipation: A Cross-National Comparison. Government Information Quarterly. 31, 4, 526-533.

Hughes, K. 2014. The Limits of Freedom of Information and Human Rights, and the Possibilities of the Common Law. Cambridge Law Journal. 73, 3, 471-474.

Irwin, T. 2013. Shining a Light on the Mysteries of State: The Origins of Fiscal Transparency in Western Europe. International Monetary Fund, Issues 13-219, IMF working paper. FOIAonline. https://foiaonline.regulations.gov/foia/action/public/home

Liang, H. and Xue, Y. 2009). Avoidance of Information Technology Threats: A Theoretical Perspective. MIS Quarterly. 33, 1, 71-90.

Madison, J. (August 4, 1822). Letter from James Madison to W.T. Barry. In G. Hunt, ed. The Writings of James Madison (New York: G.P. Putnam's Sons), 1900.

Mardiana, S., Tjakraatmadja, J. and Aprianingsih, A. 2015. Validating the Conceptual Model for Predicting Intention to Use as Part of Information System Success Model: The Case of an Indonesian Government Agency. Procedia Computer Science. The Third Information Systems International Conference [online] http://www.science direct.com/science/journal/18770509

Mitchell, K. 2014. FOIA Portal Moving from Idea to Reality. The National Archives: The FOIA Ombudsman [online]. http://foia.blogs.archives.gov/2012/01/09/foia-portal-mo ving-from-idea-to-reality/

Morey, T., Forbath, T. and Schoop, A. 2015. Customer Data: Designing for Transparency and Trust. Harvard Business Review. 92, 5, 96-105.

Mpinganjira, M. 2015. Use of e-Government Services: The Role of Trust. International Journal ofEmerging Markets. 10, 4, 622-633.

Oltmann, S., Rosenbaum, H. and Hara, N. 2006. Digital Access to Government Information: To What Extent Are Agencies in Compliance with E-FOIA? Proceedings of the 69th Annual Meeting of the American Society for Information Science and Technology. 43 (Medford, NJ: Information Today, Inc.)

OpenTheGovernment.ORG: Americans for Less Secrecy, More Democracy (Jan. 22, 2013). A Status Report on FOIAonline [online] http://www.openthegovernment.org/ node/3835 
Patel, H. and Jacobson, D. 2008. Factors Influencing Citizen Adoption of e-Government: A Review and Critical Assessment. ECIS Proceedings. Paper 76 [online] http://aisel. aisnet.org/ecis2008/ 176/

Patton, M. (1990). Qualitative Evaluation and Research Methods. Beverly Hills, CA: Sage Publications.

Rana, N. and Dwivedi, Y. 2015. Citizen's Adoption of an e-Government System: Validating Extended Social Cognitive Theory (SCT). Government Information Quarterly. 32, 2, 172-181.

Rony, M. 2012. eParticipation Research: Moving Characterization Forward (2006-2011). Government Information Quarterly. 29, 3, 346-360.

Shepherd, E. 2015). Freedom of Information, Right to Access Information, Open Data: Who is at the Table? The Round Table. 104, 6, 715-726.

Taipale, S. 2013. The Use of e-Government Services and the Internet: The Role of SocioDemographic, Economic and Geographical Predictors. Telecommunications Policy. $37,4 / 5,413-422$.

US Department of Justice. What are FOIA exemptions? [online] https://www.foia.gov/faq. html\#exemptions

US Department of Justice. Summary of Annual FOAI Reports for Fiscal Year 2014. [online] http://www.justice.gov/sites/default/files/oip/pages/attachments/2015/05/01/ fy_2014_annual_report_summary.pdf

US Government Accountability Office. 2008. Report to Congressional Requesters Information Security: Protecting Personally Identifiable Information.Washington DC [online] http://www.gao.gov/new.items/d08343.pdf.

US Senate Committee of the Judiciary. 1974. Freedom of Information Act Source Book: Legislative Materials, Cases, Articles. Washington DC. [online] http://www.llsdc. org/assets/sourcebook/foia-lh.pdf.

US Senate Committee of the Judiciary. 2015. FOIA Improvement Act of 2105. Report 1144. Washington DC. [online] https://www.gpo.gov/fdsys/pkg/CRPT-114srpt4/pdf/CR PT-114srpt4.pdf.

Worthy, B. 2010. More Open but Not More Trusted? The Effect of the Freedom of Information Act 2000 on the United Kingdom Central Government. Governance. 23, $4,561-582$.

Zuiderwijk, A, Janssen, M. and Dwivedi, Y. 2015. Acceptance and Use Predictors of Open Data Technologies: Drawing upon the Unified Theory of Acceptance and Use of Technology. Government Information Quarterly. 32, 4, 429-440. 


\title{
A Multimodal Analysis Using an Exemplar from Japanese Television Advertising
}

\author{
By Noel Murray*
}

\begin{abstract}
A multimodal analysis is used to investigate for the presence of situated meanings of uchi/soto in Japanese advertising. The analysis supports the proposition that discourses of gendered relations of uchi/soto may be found in contemporary Japanese television advertising. The article argues that relations of uchi/soto provide a unique window into Japanese consumption behavior. I advocate for multimodal critical discourse analysis as a preferred methodology and theoretical framework for multimodal advertising research applications. I discuss social and economic implications of reproducing gendered relations of uchi/soto in advertising and offer suggestions for future research on situated meanings.
\end{abstract}

Keywords: Advertising, cultural praxis, gendered relations, Multimodal Critical Discourse Analysis (MDCA), situated meaning.

\section{Introduction}

Uchi/soto (inside/outside) relations have been extensively studied in contemporary Japanese society (Ashby, 2013a; Bachnik, 1994a). Their role is illustrated in a variety of Japanese social contexts including the organization of gender, hierarchical social relations, family businesses, and intercompany business transactions. Uchi/soto functions as a type of situated meaning or cultural praxis. A central research question is whether these types of situated meanings, previously identified in real-life settings and using standard ethnographic methods, are revealed and can be detected in contemporary Japanese television advertising. Uchi/soto positionalities have already been identified in other fictional popular culture artifacts, such as novels (Molasky, 1994), contemporary anime, Taisho Baseball Girls (Ashby 2013b). This study focuses on contemporary consumer advertising and examines the role of uchi/soto relations in Japanese consumption contexts, as revealed by a single, exemplar television commercial for a food product. The television commercial provides the particulars of context that makes rhetorical study grounded and provides a critical element in the process of meaning making that is central to this study (Lyon, 2010). In this setting, the role of constructed situated meanings, such as uchi/soto, potentially becomes quite powerful in shaping societal role expectations. This premise is especially true given the stealth nature of advertising as a carrier of ideological meanings (Appadurai, 1996). The social and economic implications of such gender modeling for contemporary Japan are considerable (Pesek, 2014).

Ashby (2013a) has recently drawn attention to the fact the inside/outside trope in the Japanese use of uchi/soto is not unique to Japan. Spatial metaphors have a prominent role in Euro-American rhetoric and composition scholarship. Reynolds

\footnotetext{
*Associate Professor of Marketing \& International Business, Director of Schmid Center for International Business, Argyros School of Business \& Economics, Chapman University, USA.
} 
(2004) cites the example of Phaedrus where Plato describes the scene involving the move from inside of Athens to outside, into the countryside. Additionally, Rice (2012) discusses topoi and its critical role in Aristotle's theories of rhetoric and rhetorical spaces (p. 203). Bachnik and her colleagues, in the influential edited collection in Situated Meaning: Inside and Outside in Japanese Self, Society, and Language see uchi/soto as an alternative to Euro-American models of self and have focused on small-scale interpersonal interactions in Japan. Ashby however sees the concepts' applicability at a macro level, with the possibility of indexing degrees of cultural shared/nonsharedness. He illustrates this potential using Konagaya's study of how foreign products and cultural rituals, such as the Japanese Christmas Cake, become progressively domesticated over time (Konagaya, 2001). Finally, Chino (2001) employs the inside/outside trope to demonstrate the historical process whereby Japanese art accommodates influences of Tang Chinese art into Japanese culture while also preserving older Japanese traditions. Chino model demonstrates how one can strategically reconstitute meanings of place by repurposing pieces and styles of art.

I employ the terms uchi/soto here as part of the theory of cultural praxis, as laid out by Bachnik and her colleagues (Bachnik \& Quinn, 1994) and as an illustration of both a micro and macro theory of intercultural rhetoric, using the theory of inside/outside positionalities of Ashby (2013a).

The research methodology employed in this study draws its roots from the seminal work of Barthes (1977) on image and text. It also employs more recent developments in Multimodal Critical Discourse Analysis (MDCA) by Kress and Van Leeuwen (1996/2006). The paper addresses deficiencies in contemporary content analysis and semiotic analyses, both frequently employed in academic marketing literature.

The paper proceeds as follows. First, we review the role of situated meanings of uchi/soto in contemporary Japanese society. Second, we discuss the criteria and selection process for an exemplar example of Japanese television advertising most likely to reveal the presence of uchi/soto modeling in a fictionalized consumption context. Third, we discuss the state of the art in MCDA and its suitability as a preferred methodology and theoretical framework for multimodal research applications such as contemporary television or web-based advertising. Fourth, we investigate whether our exemplar subject, the Yamaki television commercial, supports the proposition that uchi/soto relations are revealed in contemporary Japanese advertising. Finally, we discuss social and economic implications of this finding for the role of gender relations in Japan and offer suggestions for future research on situated meanings in advertising.

\section{Situated Meaning: Uchi/Soto (Inside/Outside) in Contemporary Japan}

Uchi/soto expressions are used in Japan to communicate inside/outside contexts. Quinn calls for further research on the role of uchi/soto expressions since the concept addresses a wide range of Japanese life that is routinely symbolized as inside or outside (Quinn, 1994). Uchi/soto coordinates are a vital window into Japanese concept of self, society and language (Bachnik \& Quinn, 1994). The 
concept has crossed disciplinary boundaries of linguistics, anthropology, sociology and comparative literature. The indexical relations manifest in uchi/soto distinctions have been studied in a number of settings, including the organization of gender, hierarchy, family and family businesses (Quinn, 1994).

Uchi expressions signify a world that is enclosed, at home, family, shared, familiar, informal, private, experienced directly, known, sacred, and primary. Soto expressions indicate a world that is at work, open, non-family, formal, not shared, unfamiliar, public, observed, profane, and secondary. These inside/outside coordinates are critical to understanding the role of self and society in Japan (Bachnik, 1994b). For the Japanese, inside/outside is a basic scale along which relationships can be indexed via varying degrees of more or less. Indeed, virtually any type of relation can be mapped in relation to this scale including, bowing, gift giving, politeness or formality in speech, social space, choice of dress, or topic of conversation. In Japan, much socio-cultural information is keyed implicitly though language use. For English speaking cultures, semantic or referential meaning may play more of a role in focusing on culture as an accumulation of lexical, or general knowledge (the "what" of culture). For the Japanese, pragmatic meaning may be coded in more subtle, complex ways. Pragmatic meaning focuses on establishing connotation though cultural practices that are learned, and carried on through a process of doing (the "how" of culture). Indeed, tacit knowledge has affected the daily life of the Japanese consumer and Japanese culture throughout history (Minowa, 2012). This study employs a multimodal critical discourse analysis (see Kress \& Van Leeuwen, 1996/2006) to detect the presence of uchi/soto relations in a proto-typical Japanese family as illustrated by unpacking an exemplar television commercial for a popular Japanese food product.

\section{Exemplar Television Commerical - Yamaki}

We should not expect to see evidence of situated meanings, such as uchi/soto, in all forms of advertising. For example, informational advertising that follows a lecture format, with an off-camera announcer listing the attributes or benefits of the product would not afford an opportunity to reveal much about cultural praxis. Similarly, business to business or institutional advertising could be expected to focus more on informational appeals rather than featuring situated meanings. One would expect that product category plays an important role in whether cultural context, such as family roles and gendered behavior, it given a privileged part in how the product is presented to a prospective consumer. Parkin, for example, has provided extensive documentation that food product advertising has promoted food in distinctly gendered terms (Parkin, 2007). Food advertising has historically exhibited themes that associate shopping and cooking with women (Castonguay \& Bakir, 2019). Female heads of household have been shown serving food to demonstrate love for their families. Food advertising has facilitated and reinforced the belief that kitchen work was women's work, even as women's participation in the labor force has increased. Advertisers have promoted that using their products would give a woman a happy marriage and healthy family. Advertising has also assured women that by buying and making the right foods, a woman could help 
her family achieve social status and maintain its racial or ethnic identity. Tanaka has shown that Japanese slice-of-life television commercials represent a hyperritualized version of cultural reality and can serve as fertile ground to examine cultural praxis (Tanaka, 1994).

With these criteria in mind, the author examined a database of 1,334 digitalized Japanese television commercials from a diverse array of product categories from the popular advertising research web site Adforum.com. The goal was to identify candidates most likely to be capable of revealing the existence of situated meanings. After identifying a subset of suitable food sector candidate ads that met the above criteria, the Yamaki television commercial (more fully described below) was chosen.

\section{Methodology: Multimodal Critical Discourse Analysis (MCDA)}

There is a long tradition of semiotic analyses of print advertising in the academic advertising literature, e.g., Williamson (1978); for television advertising, there is not (Parkin, 2007). It is difficult to justify this methodological asymmetry on grounds other than operational challenges of bringing semiotic analysis to a fleeting image. However, in recent years there has been a growing interest in researching the visual, especially in technology-driven multimodal media (Rose, 2012). Work in multimodal media has been pioneered by researchers such as Forceville (1996), who examined the role of metaphors in advertisements, cartoons, and film. But even Forceville, whose work focused on cognitive metaphor theory, was mainly concerned with the static image in print advertisements and billboards. The marketing literature has a long tradition of publishing content analyses of television commercials, addressing such issues as how participants are represented and what they are represented as doing, and their gender and ethnic/racial profiles (Ball et al., 2014; Murray \& Murray, 1996). Content analyses have typically focused on breaking down the holistic communication into its constituent parts before reassembling the pieces. Improvements in computer content analyses software have helped speed up the process of analyzing the pieces but have not changed the fundamental nature of the approach (Neuendorf, 2002).

Recent developments in multimodal methods of studying popular television and film offer improved methodologies for close interrogations of multimodal media such as television commercials (Kress \& Van Leeuwen, 1996/2006; Machin \& Mayr, 2012). In particular, MCDA has become a useful methodology to address the tension between the functional/social institutional processes of the advertising industry on one hand, and the systemic part of semiosis at the level of the individual ad. MCDA has been employed to reveal dominant ideologies hidden in many forms of multimodal media (Machin, 2016). One of the advantages of MCDA over traditional content analysis is that the former is multimodal and addresses how meaning is done through complex combinations of different types of semiotic resources. For a television commercial these include the language text of the audio, the visual images in a sequence of cuts, the color 
symbolism of the mise-en-scene, and more holistic, multidimensional representations, including situated meanings, such as uchi/soto. MCDA also incorporates the contributions of sociolinguistics multimodal work in Interactional Analysis (Lincoln et al., 2017; Scollon \& Scollon, 2004). Close readings of television commercials can draw upon the work of Interaction Analysis (IA), such as Norris (2004), who has investigated the interplay of different semiotic resources such as gestures, posture and proximity in real-life environments. MCDA represents a shift in emphasis among language studies scholars from language as a site of meaning making to emphasize the interlocking role of all semiotic resources.

MCDA is not only an emerging field in its own right but operates as an approach that better locates the sign as motivated and having a particular form. MCDA also has the potential to reveal its roots in institutional ideologies, such as the advertising industry, that frames social roles and expectations. One important theoretical contribution of MCDA is the concept of affordances, the idea that different semiotic resources embedded in media, in the context of critical discourse analysis (CDA) can be strategically employed for specific ideological purposes. We will show that situated meanings, such as uchi/soto, have the potential to operate as holistic affordances, or complexes of semiotic resources to frame and prescribe family roles and expectations. In MCDA, the still image can function as a mode, but the concept of affordances allows us to skip the focus on mode and instead fix our attention on the hidden motivation of affordances.

Images, such as the still of a television commercial, can symbolize and depict in a way that language cannot (Machin, 2016). Symbols in language do not resemble what they refer to, but signify through conventions. In the case of an image, interpretation does not have to be learned in the form of a code as in language (Barthes, 1977). Consistent with Barthes' semiotic approach we privilege the role of the still image in the close reading of the Yamaki television commercial (see Figure 1a through 1f). The unique affordance of a still image is that it appears to represent unmediated reality for its audience. The still produces an ideological trick of the all-seeing spectator but hides its means of production (the ideological apparatus of the advertising industry). Sontag (2004) has long written of how advertising campaigns have the power to influence the nature of discourses about the issues they represent. Although our focus is on a singular advertising exemplar, Yamaki, the ad can serve in a Foucaultian sense (1972) as a quotation, where discourse is not so much present in any individual communication or text but in the collective force of an accumulation of similar messages from the package food industry.

Machin (2016) argues that the promise of MCDA lies in not so much in the grammar of the message but in the integration of the social into the analysis. With that in mind, we will address the following questions in our close reading of the Yamaki television commercial:

- What affordances does it bring to the overall representation of women in the situated meaning of uchi/soto?

- How does the reproduction of the uchi/soto context of the family 
relationship serve the institution of the advertising industry and what types of ideologies are reproduced in this production?

- How are the images likely to be experienced by viewers who look at them?

- What Barthesian questions are raised about the cultural meanings of the settings or by social interaction analysis?

- How can discourses about the role of womanhood in Japan shape consumption practices in the interests of the dominant ideology and the institutional practices of advertising?

- What special role do situated meanings of uchi/soto play at the level of affordances in how discourses are recontextualized to reframe social practice?

For television commercials, the frames exist in a reflective relationship to the storyboard, the architectural design for the complete message system (Moriarty et al., 2018). Thus, this research studies both textual and visual elements in the Yamaki television commercial to reveal latent content of cultural praxis, the situated meaning of uchi/soto. Operationally, six still frames (one for each of the six television commercial cuts) and the accompanying text message of the voiceover serve as the focus of the analysis. The exemplar television commercial chosen is from the campaign for the popular, Yamaki sauce-flavoring product. The multimodal approach employed here has its origins in the work of Barthes (1977) on image and text, but is also informed by more recent methodological developments of MDCA, such as that of Kress and Van Leeuwen (1996/2006), which focus on the interactions among the semiotic resources and affordances. The research goal is to determine whether situated meanings, such as uchi/soto relations, can be found in fictionalized, slice-of-life Japanese television commercials.

\section{Revealing Uchi/Soto Situated Meanings in the Yamaki Exemplar}

The following television commercial from Japan is for a food product, called Yamaki. Six frames from the 30 second commercial are presented for a multimodal analysis (see Figure 1a through 1f.). The analyses will focus on the interaction of the semiotic resources employed in the television commercial. The six frames represent key moments from all six cuts in the ad. Both original Japanese advertising copy and the English translation are provided. In Japanese, Mentsuyu-men means noodles and tsuyu means soup. The advertised product is a type of sauce for a noodle dish. Ichiban is a key word in the commercial and refers to number one. The Yamaki brand serves as an anthropomorphized manifestation of the husband as "hero" character; a common brand personality advertising strategy (Sciarrino \& Roberts, 2019). Both Yamaki and the husband as "hero" are number one/ichiban. He is the number one husband and Yamaki is the number one market share leader. Katsuo is a type of fish and Dashi refers to a soup soaked in fish or beef. The family unit consists of a father, mother, and young daughter. The Japanese and English translations of the television commercial audio text follow. 


\title{
Yamaki Commercial (Japanese)
}

Mother: Uchino papa wa ichiban zuki.Ichiban dennshade.

Father: Ichiban de naito.

Mother: Kaerunomo ichiban.

Daughter: Mada mizu dashi.

Mother: Ofuro mo yappari

Father: Ichiban de naito.

Mother: Onabemo yappari Katsuo. Ichiban Dashi no mentsuyude.

Father: Ichiban!!

Daughter: Mada namadashi.

All: $\quad$ Ktsuo Ichiban Dashi!!

Father Mentsuyu wa YAMAKI

\section{Yamaki Commercial (English)}

Mother: My honey likes to be number one.

He gets the train "\#1".

Father: I should be a number one...

Mother: He leaves for home the earliest in his company.

Daughter: The water is not heated yet.

Mother: He wants to the first person to takea bath, too.

Father: I should be a number one.

Mother: We eat hot pot with MENTSUYU, Katsuo Ichiban Dashi. My honey really likes the word number one.

Father: Number one!!!

Daughter: The food is not cooked yet.

All: $\quad$ Number one with fish soup!!!

Father: MENTSUYU is YAMAKI.

\begin{abstract}
Analysis
The Yamaki television commercial opens on the first key frame, a close-up head shot of the husband about to take the \#1 (first) train to the office (Figure1a). The camera lens pulls back to reveal the husband alone at an isolated train station (on track \#1 - the price to be paid for being \#1 [first] to arrive at the office). In the next frame (figure $1 b$ ) we see the dutiful husband leave the office to go directly home. The implied meaning for the viewer is that he is a "good" father (otoosan). A good father resists the temptation to play the workaholic company-man in staying late at work (soto) at the expense of favoring home (uchi). Neither does he sacrifice the needs of the family by going out drinking with the other companymen to after-hours clubs for karaoke. Key frames reveal the affordance of color symbolism to draw a distinction between the coldness of the soto context of the office environment and the warmth and playfulness of the uchi context of the home environment. This change in the settings' colors supports a narrative
\end{abstract}


development that shows movement from soto to uchi environments. Color symbolism is used to connote coldness and warmth. In frame figure 1a, the camera filter produces a cold blue/grey mis-en-scene at the train station. It is early dawn, an image of isolation and quietude, reminiscent of the time just before battle is engaged in a samurai epic. Our "hero" otoosan, also does battle on a daily basis at work to provide sustenance and support for his family.

In the second frame (figure 1b), the audience is introduced to the soto location of the hero's office. It is de-saturated of color, leaving a cold black and white frame. The color symbolism connotes an antiseptic work environment, stripped of warmth and humanity. From this remote coolness of the soto work environment our male hero leaves (ellipsis suggest the day's work at the office is complete) to seek refuge in the uchi environment of home and family. Once home, color symbolism is used as an affordance in successive television commercial frames as they become gradually warmer in color until, in frame (Figure 1f), the screen explodes with vibrant, primary colors of bright yellow (the table cloth) and fire engine red (the father's shirt). Gone is the soto attire of the formal black/grey business suit, to be replaced with the informal/uchi attire of the open neck shirt. Interaction analysis reveals a subtle interplay of gestures and posture, signifying warmth and family fun and playfulness; all contributing to enhancing the sense of verisimilitude in this fictional family enjoying an idealized $u c h i$ setting.

$U c h i$ is a place where people can retreat "to be themselves", free from the constraints of external social obligations. There are several additional semiotic resources employed in this mise-en-scene to connote an uchi environment of home. One is the ritual after-work bath. The father, in third frame (Figure 1c), can be seen indulging in child-like behavior in the bathtub - complete with floating yellow rubber duckie. The water has been prepared by his daughter. A second semiotic resource is revealed in the relaxed postures and the cozy informal banter of each member of the family unit at the dinner table in frame 6 (Figure 1f). Otoosan continues to bask in the role of number one (ichiban). He is center of attention in the camera (occupying the optical center of the frame) and center of attention in the family. His face grows in size (as the camera zooms in) to dominate the optical center of frame.

The mother (okaasan) is associated with the generative uchi orientation of facilitating family solidarity. Okaasan is the facilitator for her husband and child to enjoy the benefit of an $u c h i$ - like atmosphere. She is responsible for ensuring the emotional solidarity of the family. Interaction analysis reveals a number of semiotic resources employed to signify this generative function for the female head of household. For example, okaasan will sacrifice her desire to take an early bath until her husband finishes with his. It is tempting from an English-speaking perspective to understand husband/wife relations in terms of Western notions of status hierarchy, or unequal relations of power. Such perspectives are however misleading; no matter what the locus of the situation along the uchi/soto continuum, unequal relations exist in the form of amayakasu/amaeru. To amayakasu another, is to allow the indulgee freedom of expression, to give active love, to allow the other to be sweet or dependent. Amayakasu/amaeru functions as a secondary situated meaning is support of uchi/soto. Interaction analysis best 
illustrates its role in Yamaki. Note, the husband is quite literally \#1; he is first to take a bath, and he is first to sit down to dinner. To amaeru, is to be sweet, to accept the indulgence offered by another, and to receive love passively. This dyadic relationship between husband and wife, of giving and receiving indulgence, or dependence, is born and reproduced in relations of hierarchy (Doi, 1973). In the Yamaki commercial, father and child are both on the amaeru side of the relationship and can enjoy the relaxed atmosphere of a prepared bath (husband) and evening dinner. Okaasan endures tension at the level of the individual in the form of amayakasu to husband and daughter for the sake of creating meaning at the level of the relationship and family. The mother maintains enough detachment to clean the kitchen (Figure 1e), draw the bath (Figure 1c) and serve the meal (Figure 1f). The mother is responsible to father and daughter for supplying the material objects to make the evening relaxing and engaged. She exhibits a special responsibility towards the father's needs, thus creating an uchi atmosphere. Most of her actions towards the husband are characterized by disciplined action -more of soto context. The father may behave in uchi-like behavior toward the mother. $\mathrm{He}$ soaks in her attention and plays out his hierarchical role as \#1 to the hilt. At the level of the relationship, the disciplined actions of the mother are juxtaposed to the spontaneous, playful actions of the father. What are the feelings of the mother involved in this juxtaposition of a soto relationship in an uchi context? These relations create tension and subordination. The wife endures tension at the level of the individual for the sake of creating harmony at the level of the family (Lebra, 1976).

For the husband, at work, he is in a soto context, where workers are expected to be self-disciplined. At the office, he is expected to detach himself from his personal feelings and to focus on representing his work group in relation to other groups, such as competitors and customers. Gender relations in Japan do not always easily fit into Western notions of superior, inferior, or hierarchical. From the perspective of individual rights and obligations to have economic and political control, gender relations in Japan are unfair - they subordinate and cause tensions for women. From the perspective of rights to nurture family and self, gender relations are unfair - men are deprived. Thus, the okaasan is free to indulge herself in creative activities at home, to spend time nurturing her relationship with her daughter, while the otoosan must satisfy himself with the business warrior role and the unfriendly, competitive soto context of the work environment. The nature of hierarchy in Japan is that unequal relations take the form amaeru/amayakasu and these relations shift positions along an axis ranging from private to public, spontaneity to discipline (uchi/soto).

It is possible, for example, for a woman to be on the amayakasu side of an amaeru/amayakasu relationship in a soto situation. If we change the situation in frame six (figure 1f) from a cozy dinner at home (uchi context) to dinner at an exclusive restaurant (soto context), the husband may take responsibility for directing the proceedings, placing the woman on the amayakasu side of the relationship. 
Figure 1. Yamaki Television Commercial

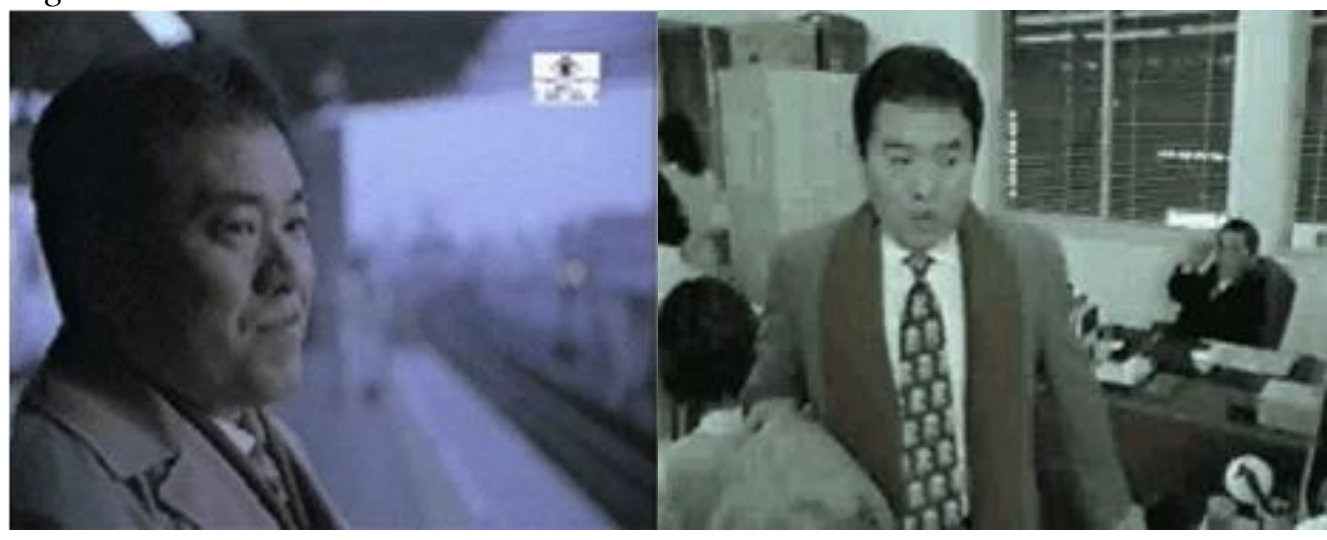

Figure 1a. Yamaki.

Figure $1 b$. Yamaki

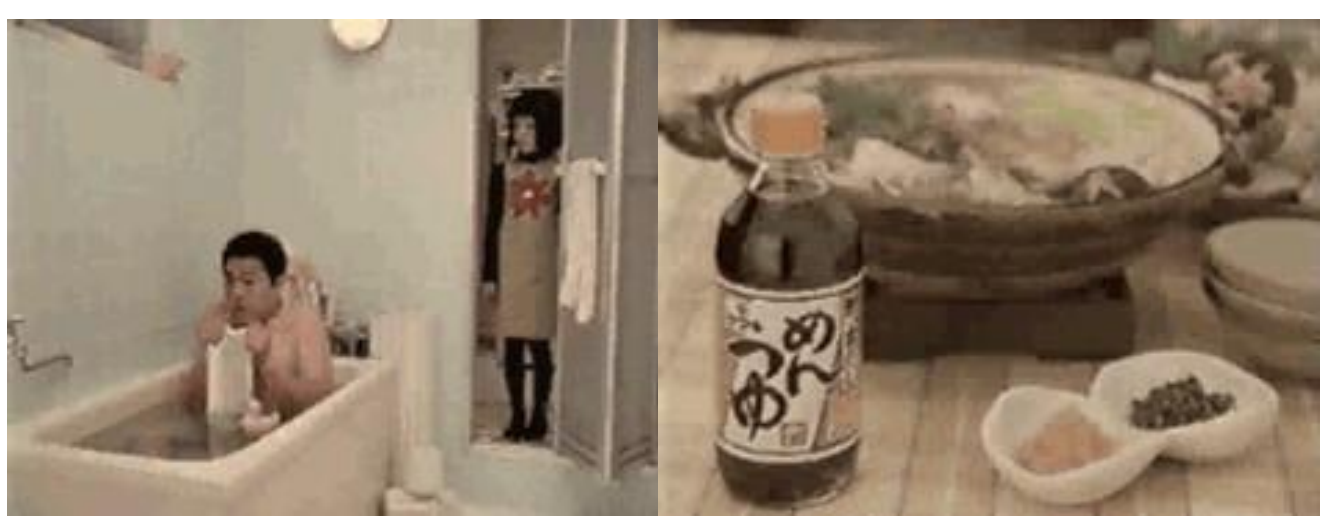

Figure 1c. Yamaki

Figure 1d. Yamaki

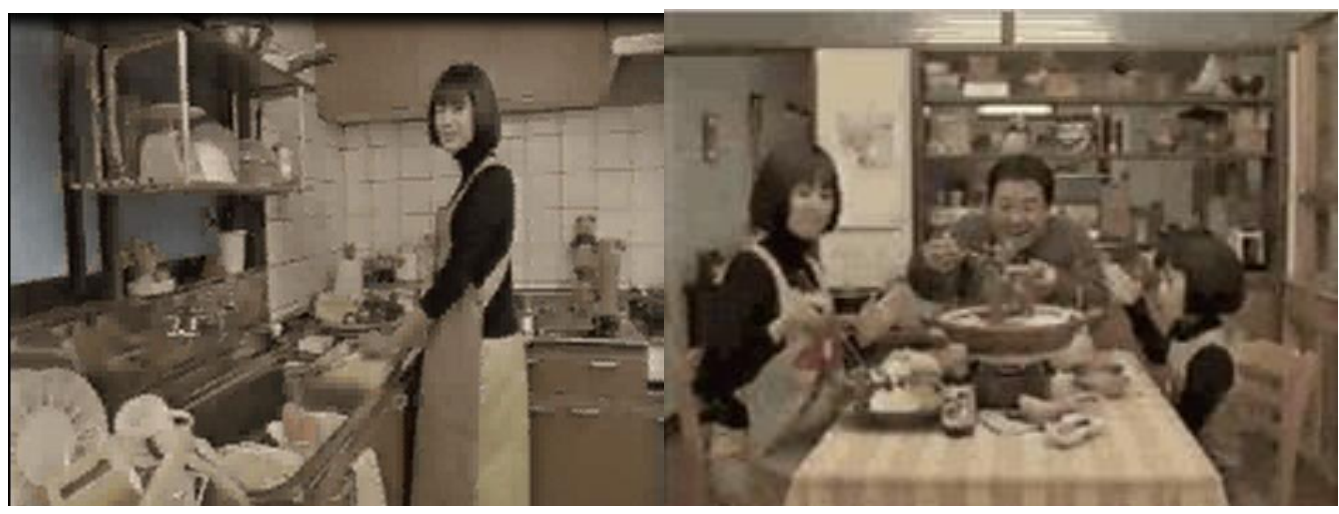

Figure 1e. Yamaki

Figure 1f. Yamaki

In a business setting, position trumps gender when women head corporations or political parties (Bachnik, 1994b). Setting therefore becomes a key semiotic resource to code which patterns of behaviors are expected of each participant in 
this carefully choreographed dance of relationships. The distinction between public and private places is critical to indexical meaning in Japan, and to decoding the meaning of gender relations. Interaction analysis also reveals a permutation of this flipping of roles in the relationship between father and child. Here -in an $u c h i$ context- otoosan may play the indulging (amayakasu) role to the young daughter by permitting her to shine through her cute dependence (amaeru). In the television commercial, the daughter takes liberty with her father when she shouts at him (playfully) "the water is not hot yet" and "the food is not cooked yet". However, the relationship could flip in an instant if the daughter were to violate her ascribed cuteness role by refusing to eat her dinner. Such behavioral transgressions could prompt otoosan to shift to a more authoritarian mode -an axial shift in the relationship to a more soto dimension. The meaning of uchi/soto is constantly changing and can only be grasped in situ.

\section{Discussion}

The close reading of the exemplar Yamaki supports our central proposition that situated meanings, such as uchi/soto relations, are found and reproduced in fictional but institutionally controlled settings such as commercial television advertising. This is significant because the focus on situated meanings in the literature has been on ethnographically documented real-life settings. We advance the proposition that since television advertising frequently depicts a hyper-realized version of cultural reality, it serves as a fertile ground to examine cultural praxis, including the role of situated meanings, such as uchi/soto. Further, we have shown how uchi/soto relations, reproduced in institutionally controlled contexts of advertising, may depict highly gendered representations of female heads of households. The representations of gendered relations may appear to be "natural" but given the stealth nature of advertising's effects on normative behavior, their impact on a broader society may be powerful. The semiotic codes produced and reproduced (through advertising repetition) in the Yamaki television advertising campaign are themselves the product of a historically and geographically specific formation or process of representation. Although codes of 'good homemaker' purport to represent universal truths, they are historically contingent truths that obscure and maintain power. In this case they are the product of a fictional household relationship circumscribed by gendered relations of uchi/soto and amaeru/amayakasu.

Marketing is thus actively implicated in the historical process of meaning production and signification when it reproduces situated meanings in fictional contexts such as slice-of-life television commercials. The attractiveness to the advertising industry of trading in semiotic resources, such as situated meanings, should be clear. The situated meanings provide a convenient short hand to communicate efficiently, piggybacking on widely held cultural assumptions about daily cultural praxis. Like the trading in stereotypes that advertising has historically been implicated in, trading in situated meanings - itself a type of abstract stereotype - offers semiotic affordances to an industry motivated more by 
easy appearances than by universal truths. One should not conclude from this study that the advertising industry's trading in situated meanings such as amaeru/ amayakasu is always managerially effective. There is considerable evidence that certain consumer product categories have historically been promoted by the advertising industry in Japan in stereotypically gendered ways (Akamatsu, 2010). Parkin (2007) argues that the food industry is one which has historically clung to outmoded discourses of motherhood. Newer generations of Japanese women may not subscribe to such gendered role expectations. Douglas Holt (2004) writes of the importance of intergenerational "cultural fissures" that may provide the source material for the creation of new mythic or iconic brands. The advertising industry is thus charged with a choice of finding the "new" rather than simply reproducing the "old".

The study also raises questions of methodology. In the marketing literature content analyses have traditionally been the preferred methodology to examine gendered relations in advertising. It is questionable whether that approach, in breaking down holistic multimodal communications into their constituent parts before reassembling the pieces is sufficiently powerful to reveal the multifaceted interplay of semiotic resources at play in contemporary media. The Yamaki ad reveals a complex array of multimodal semiotic resources -language text, still visuals, color symbolism, gestures, interaction proximity, situated meanings, miseen-scene, lighting, set production, genre- all interacting to produce a proffered "truth" for the television audience. Cultural forms such as contemporary television and newer digital media construct our knowledge of the world. While earlier forms of the image were celebrated for their power to document independent reality, newer methodologies must show greater analytical power in revealing how multimodal media have come to construct reality. The visual grammar of Yamaki can only tell us so much. We also need to ask what the medium is used for and by whom? Which social practices are they part of and what societal institutions control their message? Machin's (2016) concept of affordance may play a key role here in de-emphasizing the role of mode -itself an increasingly problematic concept in an era of multimodal and digital media- and focusing more on the motivation of the semiotic resource. In this paper we have seen how institutional players, including the advertising industry, are tasked with the choice of reproducing existing situated meanings or challenging older ones with newer formulations.

It remains an open question to what extent highly gendered constructions of female married roles, institutionally reproduced by the Japanese advertising industry, foster broader macroeconomic economic concerns evidenced by Japan's second decade of economic stagnation. A subfield of economics, coined as "womanomics" (Pesek, 2014) lays a considerable part of the blame for Japan's poor economic performance, relative to other OECD economies, on the dismal participation rate of married women in senior positions in corporate Japan. Do institutionalized discourses of women's role in popular media culture in Japan, including the advertising industry, exasperate the problem? The exemplar Yamaki, in reproducing highly gendered role expectations in uchi/soto and amaeru/ amayakasu relations, whereby woman's role is highly circumscribed within the 
home, though a singular quotation in a much larger text, questions the role of the Japanese advertising industry in what is clearly a national economic challenge.

\section{Conclusions and Future Research}

Outside of advertising, relations captured by Uchi/Soto offers fertile ground for future research in broader business and consumption contexts. It would be interesting to examine the role of uchi/soto relations in ethnographic consumption contexts, such as marketplace behavior. One could examine how speakers designate $u$ chi/soto distinctions in actual speech situations involving sellers and buyers at a marketplace. Interactional Analysis may offer a promising methodology here. There is a continuing need to develop pragmatist theories that treat meaning as emerging from social action and to analyze cultural patterns as a reflection of hierarchy and material interest. Rosenberger suggests that $u$ chi/soto relationships are fundamental to understanding the role of gender and hierarchy in business organizations. Although female employees in Japan are most often depicted as being on the amaeru side of the amaykasu/amaeru relationship, it would be interesting to further investigate to what extent position in a business organization would trump gender. When females head departments or serve as presidents of companies, do we find evidence that position dominates gender? Japanese businesses' well documented gender issues would appear to be fertile ground for such research. The dynamic interplay between indexical relations of uchi/soto would seem to challenge Western management concepts of gender, hierarchy, and power, at least in terms of how they play out in a Japanese, and perhaps more broadly, East Asian business context. One important question the present research does not address is how the reproduction of gendered relationships, framed in relations of uchi/soto and amaeru/amayakasu, are experienced by viewers who look at them. Each of the three fictional roles of mother, father and young daughter depicted in Yamaki would presumably interpret the proffered social reality quite differently. Reader Response Theory could perhaps shine some light on these questions.

I have treated uchi/soto distinctions in this paper as an intra-cultural concept. It would be interesting however to examine its role as an inter-cultural concept. Inside/outside positionalities create a framework for greater intercultural understanding by tracing points of connectedness where discrete divisions are imaged. Inside/outside positionalities also offer an alternative to an over-reliance on nation-bound methodologies and notions of identity.

\section{References}

Akamatsu, R. (2010). Content analysis of television commercials for snacks and of snack packaging targeted at children. Japanese Journal of Public Health, 57(6), 467-474.

Alexander, J. (2004). Cultural pragmatics: social performance between ritual and strategy. Sociological Theory, 22(4), 527-573.

Appadurai, A. (1996). Modernity at Large: Cultural Dimensions of Globalization. University 
of Minnesota Press.

Ashby, D. (2013a). Uchi/Soto in Japan: A global turn. Rhetoric Society Quarterly, 43(3), 256- 269.

Ashby, D. (2013b). Enacting a rhetoric of inside-outside positionalities: From the indexing practice of uchi/soto to reiterative process of meaning making. Doctoral dissertation. Miami University. Oxford. Ohio.

Bachnik, J. (1994a). Challenging our conceptualizations of self, social order, and language. In Situated Meaning: Inside and Outside in Japanese Self, Society, and Language, J. Bachnik \& C. Quinn (eds), (pp. 3-37). Princeton, New Jersey: Princeton University Press.

Bachnik, J. (1994b). Indexing self and society in Japanese family organization. In Situated Meaning: Inside and Outside in Japanese Self, Society, and Language, J. Bachnik \& C. Quinn (eds), (pp. 143-167). Princeton University Press. Princeton, New Jersey.

Bachnik, J., \& Quinn, C. (1994). Situated Meaning: Inside and Outside in Japanese Self, Society, and Language, J. Bachnik \& C. Quinn (eds). Princeton, New Jersey: Princeton University Press.

Barthes, R. (1977). Image, Music, Text. Noonday Press.

Ball, J., Liang, A., \& Lee, W. (2014). Potential for Stigma Reduction through Direct-toConsumer Prescription Drug Advertising: An Exploratory Content Analysis of Television Commercials. Journal of Current Issues \& Research in Advertising, 35(2), 190-208.

Castonguay, J., \& Aysen, A. (2019). You eat 'like a girl': gender differences in content and effects of food advertising depicting sports. Journal of Food Products Marketing, 25(3), 233-256.

Doi, T. (1973). The Anatomy of Dependence. Tokyo: Kodansha International.

Forceville, C. (1996). Pictorial Metaphor in Advertising. London. Routledge.

Foucault M. (1972). The Archaeology of Knowledge. London: Tavistock.

Holt, D. (2004). How Brands Become Icons: The Principles of Cultural Branding. Boston: Harvard Business School Press.

Konagaya, H. (2001). The Christmas Cake: A Japanese Tradition of American Prosperity. Journal of Popular Culture, 43(4), 121-136.

Kress, G., \& Van Leeuwen, T. (2006/1996). Reading Images: The Grammar of Visual Design. London. Routledge

Lebra, T. (1976). Japanese Patterns of Behavior. Honolulu: University of Hawaii Press.

Lincoln, C., Russell, B., Donohue, E., Racine, L. (2017). Mother-Child Interactions and Preschoolers' Emotion Regulation Outcomes: Nurturing Autonomous Emotion Regulation. Journal of Child \& Family Studies, 26(2), 559-573.

Lyon, A. (2010). Relationships with the Other in the Analects, Daodejing, and HanFeizi. College English, 72(4), 350-366.

Machin, D. (2016). The Need for a Social and Affordance-Driven Multimodel Critical Discourse Studies in Discourse and Society, 27(3), 322-334.

Machin, D., \& Mayr, A. (2012). How to Do Critical Discourse Analysis. London: Sage.

Minowa, Y. (2012). Practicing $Q i$ and consuming Ki: Folk epistemology and consumption rituals in Japan. Marketing Theory 12(1), 27-44.

Molasky, M. (1994). When uchi and soto fell silent in the night: Shifting boundaries in Shoga Naoya's "The Razor". In Situated Meaning: Inside and Outside in Japanese Self, Society, and Language, J. Bachnik and C. Quinn (eds.), (pp. 209-222). Princeton, New Jersey: Princeton University Press.

Moriarty, S., Mitchell, N., Wood, C., \& Wells, W. (2018). Advertising \& IMC: Principles and Practice $\left(11^{\text {th }}\right.$ ed.). Pearson.

Murray, N., \& Murray, S. (1996). Music and lyrics in commercials: A cross-cultural 
comparison between commercials run in the Dominican Republic and in the United States. Journal of Advertising, 25(2), 51-63.

Neuendorf, K. (2002). The Content Analysis Guidebook. London: Sage Publications.

Norris, S. (2004). Analyzing Multimodal Interaction London: Routledge.

Parkin, K. (2007). Food is Love: Advertising and Gender Roles in Modern America. University of Pennsylvania Press

Pesek, W. (2014). Japanization: What the World Can Learn from Japan's Lost Decades. Singapore: Bloomberg Press (Wiley).

Reynolds, N. (2004). Geographies of Writing: Inhabiting Places and Encountering Difference. Carbondale: Southern Illinois University Press.

Rice, J. (2012). From Architectonic to Tectonics: Introducing Regional Rhetorics. Rhetoric Society Quarterly, 42(2), 201-213.

Rose, G. (2012). Visual Methodologies. London: Sage.

Rosenenberger, N. (1994). Indexing Hierarchy through Japanese Gender Relations. In Situated Meaning: Inside and Outside in Japanese Self, Society, and Language, J. Bachnik, \& C. Quinn (eds.), (pp. 38-71). Princeton, New Jersey: Princeton University Press.

Quinn, C. (1994). The Terms Uchi and Soto as Windows on a World. In Situated Meaning: Inside and Outside in Japanese Self, Society, and Language, J. Bachnik \& C. Quinn (eds.), (pp. 38-71). Princeton, New Jersey: Princeton University Press.

Sciarrino, J., \& Roberts, P. (2019). Rethinking hero archetypal branding: Investigating the effects of authenticity and flawed archetypes on brand attachment and selfcongruence. Journal of Brand Strategy, 7(3), 283-295.

Scollon, R., \& Scollon, S. (2004). Nexus Analysis. London.

Sontag, S. (2004). Regarding the Pain of Others. London: Penguin Books.

Tanaka, K. (1994). Advertising Langauge: A Pragmatic Approach to Advertisements in Britain and Japan. London: Routledge.

Tyson, L. (2006). Critical theory today: a user-friendly guide, $2^{\text {nd }}$ ed. New York: Routledge. Williamson, J. (1978). Decoding Advertisements: Ideology and Meaning in Advertising. London: Marion Boyars Publishers Ltd. 



\title{
Meta-Analysis on Visual Persuasion- Does Adding Images to Texts Influence Persuasion?
}

\author{
By Kiwon Seo
}

\begin{abstract}
Compared to verbal texts, the effects of visual images on persuasion have not been sufficiently researched. The current meta-analysis investigates this under-tested topic by examining whether adding images to texts influences persuasive outcomes. The literature search found 20 effect sizes from 12 studies with a total of 2,452 participants. The overall effects show that additional visual images to verbal texts had no significant effect on persuasion, $r=0.055, p=0.161$. When moderating variables were included, however, several significant visual effects were emerged, such that photographs $(r=0.077$, $p=0.038)$, positive images $(r=0.185, p=0.000)$, and images about health issues $(r=0.105, p=0.015)$ showed significant advantages of increasing persuasion. Limitations and future directions of the study are also discussed.
\end{abstract}

Keywords: meta-analysis, persuasion, visual image.

\section{Introduction}

Communication scholars have long sought for message characteristics that increase persuasion. Throughout numerous research projects, they have provided convincing evidence that certain message features lead to better persuasion outcomes. The existing research, however, heavily focuses on one specific element in messages-verbal text-and relatively has paid less attention to other portion that also may influence persuasion-visual elements. Visual elements include various visible message components that affect message assessment, including font (Juni \& Gross, 2008), color (Gerend \& Sias, 2009), or images. The current research project focuses on the effects of visual images. Specifically, it examines whether adding images to verbal texts influences persuasion outcomes through a metaanalysis technique.

Few studies reviewed the effects of visual image. There is one outdated metaanalysis of picture effect on comprehension (Readence \& Moore, 1981). A more recent review (Houts, Doak, Doak, \& Loscalzo, 2006) covers various outcomes that visual images have in communicating health-relevant issues, but it utilizes a narrative approach that lacks an overall summary effect size (Borenstein, Hedges, Higgins, \& Rothstein, 2009). Given these limited findings, the current project starts from a relatively basic, straightforward examination of image's persuasive effects: Presence versus absence of images in texts. The following section first reviews the previous literatures that tested the effects of visual images on attention, memory, emotion and persuasion. After this review, two theoretical grounds that account for why additional images to texts can influence persuasion will be discussed.

\footnotetext{
*Assistant Professor, Sam Houston State University, USA.
} 


\title{
Empirical Findings: Research on the Effects of Visual Images
}

\begin{abstract}
Attention
One distinctive feature of visual image is its eye-catching effect (Finn, 1988; MacKenzie, 1986). Using eye-tracking equipment in a laboratory setting, studies have shown that visual images are superior to verbal-only messages in drawing attention (Deubel \& Schneider, 1993), regardless of image sizes (Pieters \& Wedel, 2004). Visual attention refers to an operation that prioritizes a certain part of the brain enhances the activation of information, and diminishes the threshold for processing information (Deubel \& Schneider, 1993). Simply, without specific instructions of message processing or reading order, people tend to first see the visual, rather than verbal part of the message. Attention to visual images also affect subsequent product involvement, attitude, and recall (Rosbergen, Pieters, \& Wedel, 1997).
\end{abstract}

\section{Memorability}

Visual images can also enhance memorability of a message, which is socalled picture superiority effect (Nelson, Reed, \& Walling, 1976). Childers and Houston (1984) found that messages containing visual images produced better recall than verbal-only messages when people did not process the message deeply. Semantically inconsistent visual images to verbal texts enhance memory as well (Houston, Childers, \& Heckler, 1987). On this picture superiority effect, MacInnis and Price (1987) posit that both verbal and visual information processing effectively formulate problems. But verbal information processing contributes an implicit or explicit summary of message-target attributes and features, whereas visual information processing contributes a holistic evaluation of the target. Thus, final outcomes of message recall tend to be differentiated according to the presence of visual images.

\section{Emotion}

Research in consumer psychology has shown that an advertisement can stimulate positive affective experiences, which further lead to increased persuasion outcomes, such as increased positive attitudes toward or behavioral intentions on the advocacies. Escalas (2004) found that positive emotion induced by the combination of a visual image (e.g., running shoes) and mental simulation (e.g., "imagine running in the shoes") effectively mediated the relationship between message and persuasion. Journalism studies also showed that messages containing both verbal and visual components were more effective in arousing positive as well as negative emotions than messages with only verbal component (Domke, Perlmutter, \& Spratt, 2002). Also journalism photographs depicting a negative event (e.g., 9/11 terrorist attack) were highly associated with negative emotions when the event was recalled (Fahmy, Cho, Wanta, \& Song, 2006). In the context of health communication, a negative emotion of fear was found to be more 
aroused by negative visual images and further to mediate the relationship between health messages and persuasion (Seo, Dillard, \& Shen, 2013).

The image's ability to arouse a certain emotional reaction has been also supported by physiological measures, such that seeing emotion-inducing images results in physiological and behavioral responses in consistent patterns (for review, Lang \& Bradley, 2008). Research utilizing functional magnetic resonance imaging (fMRI) found that emotion-arousing visual images activate neural responses in different brain regions (Pessoa, McKenna, Gutierrez, \& Ungerleider, 2002), independent of attention and awareness of emotional visual stimuli (Pessoa, 2005). Investigations using electroencephalography (EEG) also replicated the finding, such that viewing negative or positive images activate emotional reactions in corresponding areas of the brain associated with emotional activations. For example, in Harmon-Jones's (2007) study, when research participants viewed anger-inducing pictures, their left frontal cortical activity, the brain region related to the negative emotion of anger, was increased as well. Together, studies using self-report and physiology measures point out one general conclusion: Visual images can evoke emotional responses.

\section{Persuasion}

When embedded in advocacies, images also affect overall persuasion outcomes. Mitchell (1986) compared positive (sunrise) and negative (wildcat) visual images in advertisements, and found that the positive photograph led to more favorable attitude toward the messages, whereas the reverse was true for the negative one. Peracchio and Myers-Levy (2005) examined moderating role of message involvement in ads (e.g., watch and cereal). They argued that when people are required to process the message systematically, the stylistic properties of images contribute to persuasive outcomes. For example, a vertically oriented object can deliver the meaning of potency, whereas a diagonally oriented one may imply dynamism. Consistent with their reasoning, two experiments showed that compared to verbal only messages, individuals in the systematic processing condition of visual+verbal messages identified the stylistic visual properties of the products and exhibited more favorable attitude toward the stylistic messages. Similarly, Miniard, Bhatla, Lord, Dickson, and Unnava (1991) found that participants in low involvement condition used a peripheral route to make a judgment about an ad, such that when the ad contained an inappropriate, unattractive visual element (iguana), they reduced their product evaluations, whereas the reverse was true for when the ad included an appropriate, attractive element.

As reviewed so far, existing research points out the potential of visual images to influence various outcomes, directly or indirectly related to persuasion. Although most studies do not explicitly employ a specific theoretical framework, several theories provide useful accounts for why visual images are differently processed and have distinctive effects on persuasion. The following section reviews two such theories, dual coding theory and exemplification theory. 


\section{Theories of Visual Image}

\section{Dual Coding Theory}

The basic assumption of dual coding theory (Paivio, 2007) is that we build our knowledge structure from our own "perceptual, behavioral, and affective experiences with the world" and "these experiences become internalized so that cognitive representations and process are modality-specific" (p. 25). We come to know about reality based on modality-specific experiences (e.g., visual, auditory, and haptic) as our physical sensors perceive them. For instance, when we eat a certain food, we acknowledge the tastes as our gustation sensors perceive, and then we internalize, memorize, and evaluate the tastes, which results in the knowledge structure of the food. These experiences are fundamentally different from those of verbal language. In other words, word depictions of the food in terms of texture and taste are inherently different from what the physical sensors perceive, because the depictions are symbolic representations of sensory experiences, not the experiences themselves. Likewise, seeing a visual image is intrinsically different from verbal depictions of the image.

Dual coding theory classifies two functionally independent but interconnected mental subsystems: verbal and nonverbal systems. This classification is made because human beings use verbal language to think, memorize, and communicate information, but at the same time, we also utilize nonverbal information to fulfill those purposes. With the two subsystems, individuals can interpret the meaning of external stimuli by perceiving their verbal or nonverbal specific features (i.e., representational meaning) or by associating the modality specific meaning of verbal and nonverbal features (i.e., referential meaning or associative meaning). For example, when we see a photograph of a dove, we can simply perceive the object as it is seen or we can connect the object with a verbal description of "dove." The latter, associative meaning is possible because of the interconnection between two systems. Crucially, when stimuli contain both verbal and nonverbal information, verbal and nonverbal subsystems interact with each other by reinforcing or amplifying information processing, so that messages with both information types may exert more powerful message effects than messages with a single information type.

\section{Exemplification Theory}

Exemplification theory (Zillmann, 1999, 2002) postulates that human beings have evolved to pay special attention to vital events in facing with numerous external events for their welfare and survival. In contrast, trivial and irrelevant events do not receive much attention because of limited cognitive capacity. The limited capacity is also applied to vital and relevant events, so rather than processing and memorizing each individual event, human beings have evolved to selectively extract essential features of the events and to classify them into a broader category. This classification of numerous events enabled human beings to aggregate limited numbers of individual cases, so that they could use relatively 
small number of experiences to perceive and interpret a large body of similar events. The broader category acts as an exemplar.

Although exemplification theory does not particularly assume that exemplification effect is achieved through a certain message type (e.g., verbal message or verbal+visual message), studies based on this theory often employ visual images to present concrete exemplars (i.e., the "dominance of exemplification by images"; Zillmann, 2002, p. 29). Indeed, one major assumption of the theory is that concrete events are better than abstract ones for comprehension, storage, and retrieval of information. Compared to solely verbal texts, verbal+visual messages are more effective and concrete in exemplifying events, so that message recipients can easily perceive and comprehend the issue under consideration. For instance, Gibson and Zillmann (2000) examined effects of visual exemplars on risk perception with varying degrees of image depictions and they found that visual images produced the highest risk perception about the issue.

The following section discusses potential moderating variables that may interact with visual images. Existing literatures suggest three important moderators: Visual type, visual valence, and message topic.

\section{Moderators of Visual Persuasion}

First, different visual types, such as photograph, drawing, cartoon, graph, and etc., were identified because they are likely to have distinctive effects. According to Peirce (1935), characteristics associated with visual image are broadly classified into three groups: (a) resemblance to the referent (icon; e.g., photographs or pictures), (b) logical relationship between visual image and its meaning (index; e.g., figures, tables, or journalism photos that indicate something happened, acting as a proof), and (c) socially constructed meaning manifested by visual image (symbol; e.g., a national flag symbolizes the nation). This classification shows that because of their unique characteristics, each visual group tends to have different effects on communication process. For example, one distinct characteristic associated with iconic image is its ability to evoke a certain emotion (Joffe, 2008; Messaris, 1997), but in general, it is unlikely to be true to figures or tables. There may be some cases that figures or tables lead to emotional responses (e.g., a stunning fact described in a figure), but the quality and intensity of emotional experience may not be the same as that one receives from appreciating iconic images of beautiful landscapes or cute animals. Accordingly, it is necessary to distinguish each visual group and assess its effects separately.

Second, the valence of visual images was examined. As shown by message framing research (for review, O'Keefe \& Jensen, 2006), messages can emphasize different aspects of issues, which may result in different persuasion outcomes. Likewise, visual images can highlight specific parts of the message by showing positive, neutral, or negative aspects of the issue. Of course, there are various configurations of visual depictions other than the positive versus negative valence, but, as in framing research, the visual valence classification is so basic and straightforward that should be examined prior to other specifications. 
The third moderator, message topic, was closely related to visual valence, because some message topics intrinsically require positive or negative images to exemplify the issues under consideration. For instance, product or service advertisements used positive images to formulate optimistic and desirable impressions about the topic, whereas news stories often showed relatively negative examples or consequences of events, such as war, terrorism, drugs, or illegal immigration. As speculated by exemplification theory, visual exemplars may interact with certain message topics to enhance or diminish the visual effects. The moderator of message topic will examine this possibility.

\section{Methods}

\section{Literature Search}

To locate relevant reports, two undergraduate research assistants searched databases after receiving a 15-hour training that covered the purpose of this research, method of literature search, and inclusion and exclusion criteria. The searched databases included Communication and Mass Media Complete, PsycINFO, EBSCO, Educational Resources Information Center (ERIC), Business Source Complete, and Nursing and Allied Health Source. The search terms were the combinations of the following keywords: visual, image, photograph, photo, illustration, infographic, picture, cartoon, persuasion, attitude, perceived effectiveness, intention, and behavior. Image-relevant words were used in one search box as an independent variable, and persuasion-related words for another box as a dependent variable. When the assistants were unsure of whether the report met the inclusion criteria, they were instructed to include it anyway for the primary researcher to reexamine it later.

\section{Inclusion and Exclusion Criteria}

In the search, four criteria were applied. First, studies must use visual images as the main stimuli. Visual images are various static pictorial presentations in print or web-based forms, including photographs, pictures, illustrations, infographics (e.g., figures or graphs), cartoons, and so forth. Studies using video materials as main stimuli (e.g., Charry, 2014) were excluded because videos contain series of moving images and audio sound that may have distinctive effects compared to static visual images. Second, studies must utilize an experiment or field study design that compared a treatment group receiving messages of visual+verbal information and a control group reading no-image, verbal text-only messages. This criterion was imposed to examine relative effectiveness or ineffectiveness of visual image on persuasion compared to non-image message. Studies that compared different type of visual images (e.g., McQuarrie \& Mick, 1999; van Rompay, de Vries, \& van Venrooij, 2010), intensity of image descriptions (e.g., Kang \& Lin, 2015; Verlhiac, Chappé, \& Meyer, 2011), or a visual treatment group with a control group of no message recipients (e.g., Marshall, Craun, \& Theriot, 2009) were excluded from the main analysis. Third, the dependent variable must be 
persuasion, assessed by attitude change, behavioral intention, perceived effectiveness, behavioral change, or a combination of thereof. When a study employed multiple measures for persuasion (e.g., measuring attitude, behavioral intention, and perceived effectiveness in one study), the mean of the multiple measures was calculated and used as a single effect size for that study (O'Keefe \& Jensen, 2006). Finally, studies must provide statistical information to calculate the effect sizes. When studies did not provide any statistical information (e.g., Süssenbach, Niemeier, \& Glock, 2013), inaccurate information (e.g., Labranche, Helweg-Larsen, Byrd, \& Choquette, Jr, 1997), or insufficient information (e.g., Whatley, Mamdani, \& Upshur, 2002), they were excluded from the main analysis.

\section{Classification of Moderating Variables}

As discussed before, three moderating variables were identified and analyzed. First, visual type was categorized as either photograph or drawing. Contrary to our initial expectation that various image types would be emerged from the search, there were only two types of visual images. Drawing images included graphic illustrations, picture, or cartoons. The second moderator of visual valence was coded as positive, neutral, or negative. Positive images depicted desirable outcomes of advocated topic. Negative images were aversive and unwanted consequences of message depictions, such as war casualties, coffins, and troubled facial expressions. Neutral images did not possess a specific valence, but presented products, exemplars, or behaviors that acted as proofs. When a message contained both positive and negative images, and different statistics associated with separate positive or negative images were not available, the valence was coded as neutral. The last moderating variable was message topic, involving categories of advertisements, news articles, health issues, or information. Advertisements used images to exemplify the products or outcomes related to the message recommendations. In the case of news articles, the messages were selected or modified from actual news stories. Health issues were messages that advocated specific courses of action to improve or maintain individuals' health. Information messages only presented facts (e.g., contact information) or procedures (e.g., solving mathematics).

\section{Calculating Effect Sizes}

The unit of analysis for effect size was an experimental pair that a treatment condition of visual+verbal message was contrasted with a control condition of verbal-only message. There were several studies that employed multiple experiments or multiple group comparisons. As a result, 20 effect sizes from 12 studies were included in the analysis. When a study reports different statistics for different images (e.g., Willnat, Graf, \& Brewer, 2000), we calculated the statistics separately, but if it reports a combined result (e.g., Kelly, Slater, \& Karan, 2002), we calculated the result as one image effect. The statistics used in the calculation were correlations, sample sizes, means, and standard deviations. These were converted to a correlation $(r)$, an effect size indicator, and $p$ value. 


\section{Results}

\section{Effects of Visual Images}

Effect sizes were available for 20 cases with a total of 2,515 participants. A random-effects model was used instead if a fixed-effects model because of an interest in generalizing across messages (Borenstein et al., 2009). Details for each case are summarized in Table 1 . Across 20 effect sizes, additional visual images to verbal texts had a nonsignificant persuasive advantage, $r=0.055, p=0.161$.

Table 1. Sample Sizes, Correlations, and Moderating Variables

\begin{tabular}{|c|c|c|c|c|c|c|}
\hline Study Name & $N$ & $r$ & $p$ value & Visual Type & $\begin{array}{c}\text { Visual } \\
\text { Valence }\end{array}$ & $\begin{array}{l}\text { Message } \\
\text { Topic }\end{array}$ \\
\hline Kelly et al. (2002) & 384 & 0.162 & 0.001 & Photograph & Positive & Ad \\
\hline $\begin{array}{l}\text { Kisielius and Sternthal } \\
\text { (1984) Pilot Study }\end{array}$ & 43 & -0.368 & 0.009 & Drawing & Neutral & Ad \\
\hline $\begin{array}{l}\text { Kisielius and Sternthal } \\
\text { (1984) Study } 1\end{array}$ & 90 & -0.141 & 0.177 & Drawing & Neutral & Ad \\
\hline $\begin{array}{l}\text { Kisielius and Sternthal } \\
\text { (1984) Study } 2\end{array}$ & 58 & -0.231 & 0.069 & Drawing & Neutral & Ad \\
\hline $\begin{array}{l}\text { Kisielius and Sternthal } \\
\text { (1984) Study } 3\end{array}$ & 58 & 0.081 & 0.533 & Drawing & Neutral & Ad \\
\hline Martin (2004) & 160 & 0.312 & 0.000 & Photograph & Positive & Ad \\
\hline $\begin{array}{l}\text { McClure et al. (2011) } \\
\text { Positive Image }\end{array}$ & 115 & -0.050 & 0.592 & Photograph & Positive & News \\
\hline $\begin{array}{l}\text { McClure et al. (2011) } \\
\text { Negative Image }\end{array}$ & 130 & 0.146 & 0.092 & Photograph & Negative & News \\
\hline $\begin{array}{l}\text { Möller et al. (2012) } \\
\text { Drawing }\end{array}$ & 77 & 0.136 & 0.227 & Drawing & Neutral & Information \\
\hline $\begin{array}{l}\text { Möller et al. (2012) } \\
\text { Photograph }\end{array}$ & 77 & 0.035 & 0.758 & Photograph & Neutral & Information \\
\hline Pfau et al. (2006) & 118 & 0.021 & 0.819 & Photograph & Negative & News \\
\hline Sengül and Dereli (2013) & 61 & 0.462 & 0.000 & Drawing & Neutral & Information \\
\hline $\begin{array}{l}\text { Seo and Dillard (in press) } \\
\text { Gain-Match }\end{array}$ & 154 & 0.123 & 0.124 & Photograph & Positive & Ad \\
\hline $\begin{array}{l}\text { Seo and Dillard (in press) } \\
\text { Loss-Match }\end{array}$ & 145 & 0.056 & 0.500 & Photograph & Negative & Ad \\
\hline Seo et al. (2013) Flossing & 252 & 0.043 & 0.491 & Photograph & Neutral & Health \\
\hline $\begin{array}{l}\text { Seo et al. (2013) } \\
\text { Sunscreen }\end{array}$ & 252 & 0.156 & 0.012 & Photograph & Neutral & Health \\
\hline Shahab et al. (2007) & 23 & .207 & 0.308 & Photograph & Neutral & Health \\
\hline Tukachinsky et al. (2011) & 81 & -0.334 & 0.001 & Photograph & Negative & News \\
\hline $\begin{array}{l}\text { Willnat et al. (2000) } \\
\text { Drug }\end{array}$ & 88 & 0.025 & 0.817 & Photograph & Negative & News \\
\hline $\begin{array}{l}\text { Willnat et al. (2000) } \\
\text { Terrorism }\end{array}$ & 86 & 0.086 & 0.424 & Photograph & Negative & News \\
\hline Total $N$ & 2452 & & & & & \\
\hline Mean correlation & & 0.055 & 0.161 & & & \\
\hline
\end{tabular}

Moderator: visual type. As shown in Table 2, when the moderating variable of visual type was examined, messages with photographic images had a weak, but significant effect on persuasion, $r=0.077, p=0.038, k=14$, compared to 
verbal text messages. The messages with drawings did not have an effect on persuasion, $r=-0.003, p=0.982, k=6$.

Moderator: visual valence. Positive images showed a significant effect on persuasion $(r=0.185, p=0.000)$, although only four cases were included in the analysis. The most cases belong to neutral images $(k=10)$, but the effect was nonsignificant, $r=0.043, p=0.520$. Likewise, negative images did not have a significant effect on persuasion $r=-0.030, p=0.616, k=6$.

Moderator: message topic. In the case of message topic, health issues had a significant effect on persuasion, $r=0.105, p=0.015, k=3$, but again, few cases were included in the analysis. The other topics, ad ( $r=0.024, p=0.735, k=8)$, news story $(r=-0.015, p=0.822, k=6)$, and information $(r=0.218, p=0.109$, $k=3$ ), failed to show a significant effect.

Table 2. Summary Results by Moderating Conditions

\begin{tabular}{|l|c|c|c|c|}
\hline Moderators & $k$ & $\%$ & $r$ & $p$ \\
\hline Visual Type & & & & \\
\hline Photograph & 14 & 70 & 0.077 & 0.038 \\
\hline Drawing & 6 & 30 & -0.003 & 0.982 \\
\hline Visual Valence & & & & \\
\hline Positive & 4 & 20 & 0.185 & 0.000 \\
\hline Neutral & 10 & 50 & 0.043 & 0.520 \\
\hline Negative & 6 & 30 & -0.030 & 0.616 \\
\hline Message Topic & & & & \\
\hline Ad & 8 & 40 & 0.024 & 0.735 \\
\hline News & 6 & 30 & -0.015 & 0.822 \\
\hline Health & 3 & 15 & 0.105 & 0.015 \\
\hline Information & 3 & 15 & .218 & .109 \\
\hline Total experimental pairs & 20 & & & \\
\hline
\end{tabular}

Note: Effect size calculations were based on the random effects mode; $k=$ number of experimental pairs.

\section{Discussion}

The main purpose of this project was to examine whether additional images to verbal texts affect persuasion. Results from the meta-analysis with 20 effect sizes show that adding images to messages does not affect overall persuasion outcomes, measured by attitude, perceived effectiveness, behavioral intention, or behavioral change $(r=0.055, p=0.161)$.

Unlike theoretical speculations suggested before, visual images that were presumed to exemplify the message topics or to buttress the verbal descriptions of the messages did not actually influence the overall persuasion effects. However, when moderating variables were included in the analyses, certain visual conditions changed the impact of visual images. In the case of visual type, photographic images showed a significant effect in increasing persuasion $(r=0.077, p=0.038)$, 
but drawings, cartoons, or line illustrations did not $(r=-0.003, p=0.982)$. As suggested by exemplification theory (Zillmann, 1999, 2002), this relative effectiveness seems to come from photographs' ability to visualize and exemplify the message topic in more concrete and realistic ways. Although drawings, cartoons, or line illustrations are iconic signs that indicate resembled referents (Peirce, 1935), their quality and strength of representing direct reference are unlikely to be as strong as photographs. The qualities of experimental stimuli in the analyzed studies are unclear, because most of them did not include the stimuli in the reports. In the case that a study included the stimuli (e.g., Möller et al., 2012), however, the qualities of drawing are not as good and clear as those of photographs. Of course, this speculation, the persuasive quality difference between different types of visual images, needs further investigation, but still the moderator analysis presents an obvious, but important idea on visual persuasion: All images do not equally produced to enhance persuasion, and their qualities must be considered.

The analysis on the second moderator, visual valence, shows that positive images have significant effects $(r=0.185, p=0.000)$ on amplifying persuasion, but neutral $(r=0.043, p=0.520)$ and negative $(r=-0.030, p=0.616)$ did not. Those positive images were magazine advertisements of cigarette, beer, and soft drink (Kelly et al., 2002), a nonstereotypical and positive presentation of an obese woman (McClure et al., 2011), and a group of smiling people (Seo \& Dillard, in press). Because only three studies were included to the positive image category, it is still vague what aspect of these positive images showed significance. However, when other moderators are considered together, a clue can be found. The positive images were all photographs that were used to promote products (Kelly et al., 2002), a service (Seo \& Dillard, in press), or perception about a group of people (McClure et al., 2011). It appears that positive images containing certain characteristics, such as (a) realistic and clear presentations with photographs and (b) desirable and beneficial aspects of the topic.

In the case of the last moderator, message topic, the result indicates that health relevant messages enhanced persuasion $(r=0.105, p=0.015)$, but advertisement $(r=0.024, p=0.735)$, news $(r=-0.015, p=0.822)$, and informational $(r=0.218$, $p=0.109$ ) messages failed to do so. The health studies included neutrally valenced photographs that promoted healthy behaviors, similar to the moderator of visual valence. Interestingly, advertisement messages, which are closer to the idea of promotion, did not show significant effects. This nonsignificant effect mainly resulted from four effect sizes of Kisielius and Sternthal's (1984) study. They tested such conditions where visual images diminished the persuasion because of higher cognitive elaboration. The images were not photographs, but line drawings that might have had distinctive effects. Importantly, contrary to other studies, they forced participants to watch and read the ad messages in 14 pages for 5 seconds for each page. Given that the advocated topic, a new shampoo, was relatively a low involved one, this forced exposure might have acted as a confounding variable that decreased image effects. In fact, a moderator analysis without Kisielius and Sternthal (1984) show that the ad messages have a significant effect on increasing persuasion $(r=0.167, p=0.001)$. Thus, promotional images seemed to be more 
advantageous to increase persuasive outcomes.

Despite the nonsignificance of overall, additional image effect, the analyses of three moderating variables present specific image characteristics that are more likely to amplify persuasive effects. That is, (a) photographs, rather than graphic illustrations, that depict (b) positive and desirable aspects of the topic in (c) promotional messages that advocate a certain service, product, or course of action can be more persuasive. These findings, again, must be interpreted carefully, because these significant effect sizes are very small. For these findings to be more valuable and practical, more studies must be conducted.

\section{Limitations and Future Directions}

The current project is not free from several limitations. First, despite the extensive search for all relevant publications, it is possible for the search to have missed relevant studies. Because this study employed relatively specific exclusion and inclusion criteria, the possibility may be even higher than other searches with broad criteria. Second, this study only compared the presence and absence of visual images, which might have unnecessarily limited the scope of visual research. Given that there is no meta-analysis on the persuasive effects of visual image, it was determined to seek for the basic examination of visual effects. However, many studies have investigated the effects through different designs and comparisons (e.g., Gardner \& Houston, 1986; Smith, Houston, \& Childers, 1985) and found meaningful results. Thus, other studies of visual effects, beside the comparison of presence versus absence of images, should be investigated by future studies. Lastly, this study examined only three moderating variables, but other moderators are also likely to affect persuasive effects of visual images. For example, as reviewed before, many studies have found superior effects of visual images on attention, memory, and emotion, which are all relevant to persuasion. Among them, emotion is a direct and powerful outcome that influences the persuasion (Dillard \& Peck, 2001; Dillard \& Seo, 2013). Because there were few studies that actually measured emotional responses from visual images, it was not feasible to examine emotional effects. As more studies test images' ability to evoke emotions and their associations with persuasion, specific conditions of images' superior effects can be better understood.

\section{Acknowledgements}

This research project was funded by the Faculty Research Grant (FRG) at Sam Houston State University in 2016. 


\section{References}

Borenstein, M., Hedges, L. V, Higgins, J. P. T., \& Rothstein, H. R. (2009). Introduction to meta-analysis. West Sussex, United Kingdom: Wiley.

Charry, K. (2014). Product placement and the promotion of healthy food to preadolescents: When popular TV series make carrots look cool. International Journal of Advertising, 33, 599-616.

Childers, T. L., \& Houston, M. J. (1984). Conditions for a picture-superiority effect on consumer memory. Journal of Consumer Research, 11, 643-654.

Deubel, H., \& Schneider, W. X. (1993). There is no expressway to comprehensive theory of the coordination of vision, eye movements, and visual attention. Behavior and Brain Sciences, 16, 575-576.

Dillard, J. P., \& Peck, E. (2001). Persuasion and the structure of affect: Dual systems and discrete emotions as complementary models. Human Communication Research, 27, $38-68$

Dillard, J. P., \& Seo, K. (2013). Affect and persuasion. In J. P. Dillard \& L. Shen (Eds.), The SAGE handbook of persuasion (2nd ed., pp. 150-166). Thousand Oaks, CA: Sage.

Domke, D., Perlmutter, D., \& Spratt, M. (2002). The primes of our times? An examination of the 'power' of visual images. Journalism, 3, 131-159.

Escalas, J. E. (2004). Imagine yourself in the product: Mental simulation, narrative transportation, and persuasion. Journal of Advertising, 33, 37-48.

Fahmy, S., Cho, S., Wanta, W., \& Song, Y. (2006). Visual agenda-setting after 9/11: Individuals' emotions, image recall, and concern with terrorism. Visual Communication Quarterly, 13, 4-15.

Finn, A. (1988). Print ad recognition readership scores: An information processing perspective. Journal of Marketing Research, 25, 168-177.

Gardner, M. P., \& Houston, M. J. (1986). The effects of verbal and visual components of retail communications. Journal of Retailing, 62, 64-78.

Gerend, M. A., \& Sias, T. (2009). Message framing and color priming: How subtle threat cues affect persuasion. Journal of Experimental Social Psychology, 45, 999-1002.

Gibson, R., \& Zillmann, D. (2000). Reading between the photographs: The influence of incidental pictorial information on issue perception. Journalism and Mass Communication Quarterly, 77, 355-366.

Harmon-Jones, E. (2007). Trait anger predicts relative left frontal cortical activation to anger-inducing stimuli. International Journal of Psychophysiology, 66, 154-160.

Houston, M. J., Childers, T. L., \& Heckler, S. E. (1987). Picture-word consistency and the elaborative processing of advertisements. Journal of Marketing Research, 24, 359369.

Houts, P. S., Doak, C. C., Doak, L. G., \& Loscalzo, M. J. (2006). The role of pictures in improving health communication: A review of research on attention, comprehension, recall, and adherence. Patient Education and Counseling, 61, 173-190.

Joffe, H. (2008). The power of visual material: Persuasion, emotion and identification. Diogenes, 55, 84-93.

Juni, S., \& Gross, J. S. (2008). Emotional and persuasive perception of fonts. Perceptual and Motor Skills, 106, 35-42.

Kang, J., \& Lin, C. (2015). Effects of message framing and visual-fear appeals on smoker responses to antismoking ads. Journal of Health Communication, 20, 647-655.

Kelly, K. J., Slater, M. D., \& Karan, D. (2002). Image advertisements' influence on adolescents' perceptions of the desirability of beer and cigarettes. Journal of Public 
Policy \& Marketing, 21, 295-304.

Kisielius, J., \& Sternthal, B. (1984). Detecting and explaining vividness effects in attitudinal judgments. Journal of Marketing Research, 21, 54-64.

Labranche, E. R., Helweg-Larsen, M., Byrd, C., \& Choquette, Jr, R. A. (1997). To picture or not to picture: Levels of erotophobia and breast self-examination brochure techniques. Journal of Applied Social Psychology, 27, 2200-2212.

Lang, P. J., \& Bradley, M. M. (2008). Appetitive and defensive motivation is the substrate of emotion. In A. Elliot (Ed.), Handbook of approach and avoidance motivation (pp. 51-66). New York, NY: Taylor \& Francis.

MacInnis, D. J., \& Price, L. L. (1987). The role of imagery in information processing: Review and extensions. Journal of Consumer Research, 13, 473-491.

MacKenzie, S. B. (1986). The role of attention in mediating the effect of advertising on attribute importance. Journal of Consumer Research, 13, 174-195.

Marshall, H. L., Craun, S. W., \& Theriot, M. T. (2009). The big picture: How social work can effectively utilize photographs. Social Work, 54, 317-325.

Martin, T. (2004). The alma mater ask: An examination of visual and textual exemplification effects in university web-based fundrasing. Paper presented at the annual meeting of the International Communication Association, New Orleans, LA.

McClure, K. J., Puhl, R. M., \& Heuer, C. A. (2011). Obesity in the news: Do photographic images of obese persons influence antifat attitudes? Journal of Health Communication, 16, 359-371.

McQuarrie, E. F., \& Mick, D. G. (1999). Visual rhetoric in advertising: Text-interpretive, experimental, and reader-response analyses. Journal of Consumer Research, 26, 3754.

Messaris, P. (1997). Visual persuasion: The role of images in advertising. Thousand Oaks, CA: Sage Publications.

Miniard, P. W., Bhatla, S., Lord, K. R., Dickson, P. R., \& Unnava, H. R. (1991). Picturebased persuasion processes and the moderating role of involvement. Journal of Consumer Research, 18, 92-107.

Mitchell, A. (1986). The effect of verbal and visual components of advertisements on brand attitudes and attitude toward the advertisement. The Journal of Consumer Research, 13, 12-24.

Möller, B., Brezing, C., \& Unz, D. (2012). What should a corporate website look like? The influence of Gestalt principles and visualisation in website design on the degree of acceptance and recommendation. Behaviour \& Information Technology, 31, 739751.

Nelson, D. L., Reed, V. S., \& Walling, J. R. (1976). Pictorial superiority effect. Journal of Experimental Social Psychology: Human Learning and Memory, 2, 523-528.

O'Keefe, D. J., \& Jensen, J. D. (2006). The advantages of compliance or the disadvantages of noncompliance? A meta-analytic review of the relative persuasive effectiveness of gain-framed and loss-framed messages. Communication Yearbook, 30, 1-43.

Paivio, A. (2007). Mind and its evolution: A dual coding theoretical approach. New Jersey: Lawrence Erlbaum Associates.

Peirce, C. S. (1935). Collected papers of Charles Sanders Peirce. Belknap Press of Harvard University Press.

Peracchio, L. A., \& Meyers-Levy, J. (2005). Using stylistic properties of ad pictures to communicate with consumers. Journal of Consumer Research, 32, 29-40.

Pessoa, L. (2005). To what extent are emotional visual stimuli processed without attention and awareness? Current Opinion in Neurobiology, 15, 188-196.

Pessoa, L., McKenna, M., Gutierrez, E., \& Ungerleider, L. G. (2002). Neural processing 
of emotional faces requires attention. Proceeding of the National Academy of Sciences, 99, 11458-11463.

Pfau, M., Haigh, M., Fifrick, A., Holl, D., Tedesco, A., Cope, J., ... Martin, M. (2006). The effects of print news photographs of the casualties of war. Journalism \& Mass Communication Quarterly, 83, 150-168.

Pieters, R., \& Wedel, M. (2004). Attention capture and transfer in advertising: Brand, pictorial, and text-size effects. Journal of Marketing, 68, 36-50.

Readence, J. E., \& Moore, D. W. (1981). A meta-analytic review of the effect of adjunct pictures on reading comprehension. Psychology in Schools, 18, 218-224.

Rosbergen, E., Pieters, R., \& Wedel, M. (1997). Visual attention to advertising: A segment-level analysis. Journal of Consumer Research, 24, 305-314.

Sengül, S., \& Dereli, M. (2013). The effect of learning integers using cartoons on 7th grade students' attitude to mathematics. Educational Sciences: Theory and Practice, 13, 2526-2534.

Seo, K., \& Dillard, J. P. (n.d.). The persuasive effects of two stylistic elements: Framing and imagery. Communication Research.

Seo, K., Dillard, J. P., \& Shen, F. (2013). The effects of message framing and visual image on persuasion. Communication Quarterly, 61, 564-583.

Shahab, L., Hall, S., \& Marteau, T. (2007). Showing smokers with vascular disease images of their arteries to motivate cessation: A pilot study. British Journal of Health Psychology, 12, 275-283.

Smith, R. A., Houston, M. J., \& Childers, T. L. (1985). The effects of schematic memory on imaginal information processing: An empirical assessment. Psychology and Marketing, 2, 13-29.

Süssenbach, P., Niemeier, S., \& Glock, S. (2013). Effects of and attention to graphic warning labels on cigarette packages. Psychology \& Health, 28, 1192-1206.

Tukachinsky, R., Mastro, D., \& King, A. (2011). Is a picture worth a thousand words? The effect of race-related visual and verbal exemplars on attitudes and support for social policies. Mass Communication and Society, 14, 720-742.

van Rompay, T. J. L., de Vries, P. W., \& van Venrooij, X. G. (2010). More than words: On the importance of picture-text congruence in the online environment. Journal of Interactive Marketing, 24, 22-30.

Verlhiac, J.-F., Chappé, J., \& Meyer, T. (2011). Do threatening messages change intentions to give up tobacco smoking? The role of argument framing and pictures of a healthy mouth versus an unhealthy mouth. Journal of Applied Social Psychology, 41, 2104-2122.

Whatley, S., Mamdani, M., \& Upshur, R. E. G. (2002). A randomised comparison of the effect of three patient information leaflet models on older patients treatment intentions. British Journal of General Practice, 52, 483-484.

Willnat, L., Graf, J., \& Brewer, P. R. (2000). Priming international affairs: How the media influence attitudes toward foreign countries. Paper presented at the annual meeting of the Association for Education in Journalism and Mass Communication, Phoenix, AZ.

Zillmann, D. (1999). Exemplification theory: Judging the whole by some of its parts. Media Psychology, 1, 69-94.

Zillmann, D. (2002). Exemplification theory of media influence. In J. Bryant \& D. Zillmann (Eds.), Media effects: Advances in theory and research (2nd ed., pp. 1941). Mahwah, New Jersey: Lawrence Erlbaum Associates. 


\title{
Social Media Habits through a New Media Literacy Perspective: A Case of Gifted Students
}

\author{
By Naif Kara* ,Ekmel Geçer ${ }^{ \pm} \&$ Çiğdem Şahin ${ }^{\circ}$
}

\begin{abstract}
The aim of this study is to find out the problems of gifted students using social media through a new media literacy perspective and according to the results obtained, to shed light on launching new media literacy in gifted centres called Science and Art Centres, Turkey. It has been tried to determine whether gifted students who are successful in the academic field use social media consciously on the axis of new media literacy. The social media habits of gifted students in a digital perspective constitute the basic framework of this research. A quantitative approach was used in the research. In quantitative research, a random sample of total 101 gifted students, between 6-17 ages with 51 females and 50 males at Izmit Science and Art Centre in Kocaeli, was applied. The data were analysed through descriptive research model in SPSS 22 (Statistical Package for the Social Sciences) statistical program. According to the preliminary results of the study, it was found that gifted students spent a lot of time on digital media and used YouTube channel more. In this study, their new media literacy education seems to be weak and they could obtain significant information on special education through new media literacy.
\end{abstract}

Keywords: New Media Literacy, Gifted Student, Social Media.

\section{Introduction}

In Turkey, the conception of giftedness is formally accepted for a person who demonstrates higher performance than the peers in the field of intelligence, creativity, arts, sports, leadership capacity and in special academic fields (MEB, 2009). Gifted students are defined as having higher performance than their peers in their learning speed, learning level and interests. (Marland, 1972). Science and Art Centres in Turkey aim to serve qualified and advanced level education for these gifted students. In this regard, the social media habits of the gifted students will be examined.

The widespread adoption of information and communications technologies (ICT) has brought with it many social and educational benefits. Mobile phones, email, live chat applications, and social networking websites now form an intrinsic part of adolescent communication and social life (Connoly, 2018). It enables the communication quicker and limitless and makes the social media more attractive. Enthusiasts for the electronic social media argue passionately for the new ease. So often, though, the widespread assumption seems to be that these powerful new tools are good for civilisation. Some educators are keen to set up and spread electronic networks as the way forward for the development of gifted individuals (Freeman, 2014).

\footnotetext{
*PhD Candidate, Sakarya University, Social Sciences Institute, Communication Sciences, Sakarya, Turkey.

${ }^{ \pm}$Assistant Professor, Sakarya University, Media \& Journalism Studies, Department of Journalism, Sakarya, Turkey.

${ }^{\circ}$ Dr. Independent Researcher, Faculty of Education, Gaziantep University, Gaziantep, Turkey.
} 
Educators need to meet students where they live and integrate technology and social media tools into their classrooms for several reasons. The ubiquity of digital connectivity throughout the entire extent of their lifetimes has fundamentally changed how students acquire and use knowledge. For modern students, learning often requires innovative social interactions and fun (Selwyn, 2012).

Today, most of the students constitute their social lives with technology. Therefore, schools need to keep their technological equipment actual. The gifted students want to establish academic contact with their peers. They can establish contact with people from all around the world and share their experiences through technology (Biçen \& Arnavut, 2015). Many gifted students might establish contact with other gifted students by using technological tools in order to complete their identity developments (Cross, 2004).

Among the most prominent users of social media are the current generation of college students. (Grewal \& Roggeveen \& Shankaranarayanan, 2015). These students comprehend social media platforms splendidly. As early as $2007,94 \%$ of students engaged with social media to connect and socialize with friends and family (Abe \& Jordan, 2013). But beyond its importance for students' social lives, social media offers potential value as a source for education (Bal et all, 2015).

According to the National Science Foundation (1997), by 2010, one- fourth of all new jobs will be information- intensive and involve technology. Our future leaders and citizens will need to develop their skill and confidence in using and manipulating technology and information. As educators seek to provide quality educational programming to address the specialized needs of gifted learners, technology can provide an essential component in building an effective learning environment (Nugeni, 2001).

Maker and Neilson (1982) suggest that effective learning environments for gifted students have specific characteristics and student-centred. The environments should focus on self-directed learning, inventions and discoveries. They should also encourage the students for investigation. As the research of Clark (1994) started the depth in differentiated curriculum it encourages the advancement in knowledge. Technological integration in the gifted classroom is dependent upon adequate teacher training and the efforts of teachers to implement innovative technology. Teachers of gifted students should provide extra sources and grants to add and improve the available learning environments (Nugeni, 2001).

While planning appropriate educational experiences, teachers of gifted students often must acquire materials beyond what they have available in the regular curricular materials (Lewis, 1998). Teachers can find a wealth of resources for this purpose in technology from local businesses, governmental agencies, and organizations. When various technologies are incorporated into the learning environment, teachers can readily address the individual needs and learning preferences of the gifted student. Learning experiences can be structured to develop student strengths, provide flexible pacing so that they have the opportunity to work at their own speed and ability level, and encourage ownership of their learning as active participants (Jones, 1990).

Technology may lead gifted students to create new, original, and innovative products. It can prevent repeating what previously done, and expertise to build up 
independent and original studies. Furthermore, technology can empower students to seek new roles as leaders, take new learning risks, and facilitate the learning of others. It gives them practice in using tools that are applicable to the real world. Moreover, integrating technology builds competencies needed for students to become technologically literate in an information based world (Nugeni, 2001).

A study conducted by Barak (2000) reported that two major factors influenced the motivation of gifted students to study technology: (a) the desire to learn interesting subjects and (b) the expectation for long-term benefits for students who study both electronics and physics. Smutney (2011) stated that gifted students need technology and critical thinking in integrated education and thanks to this education, they become active participants.

Gifted students use all facilities of technology and perceive technology as an assistive tool for their personal developments (Cross, 2004). They can become aware of their strong and weak sides through using internet effectively (Siegle, 2001). They can also develop learning techniques and styles through technology and learn about themselves better (Lowther et all., 2012). Gifted students who have membership in more than three social media accounts reported that they feel sad and angry when there is no internet connection (Özcan \& Biçen, 2016).

The technology enables people to socialise, communicate, interact, search and learn by using applications in social media. There are both beneficial and harmful sides of social media usage in terms of quantity and quality. To examine their social media habits gains a special importance when considered the importance of the gifted students for the nations. This study makes a significant contribution to the literature from the perspective of new media literacy of gifted students.

Even though studies have been tried, in terms of social media, on gifted education there is a gap concerning new media literacy for gifted students. They exactly don't know how to utilise digital media consciously or at least there aren't enough detailed studies illustrating social media habits of gifted students with the framework of new media literacy (Kara, 2019). Continuing new media researches are insufficient to be able to respond gifted education. Studies are also inadequate because the gifted education through new media literacy is a new field compared to other educational fields.

There are very few studies in Turkey that directly contact the subject, as Köroğlu's research (2015), in which the use of social media by gifted students is analysed quantitatively, and the media literacy view of gifted students, by Gömleksiz and others (2012). In another study, it has been determined that gifted students have a pragmatic perspective in using new media when compared to ordinary users and their peers (Güzel et al., 2017).

In this study, uses and gratification theory is included. The media tells us to escape from the routine, get rid of problems, get out of worries or tensions, participate in the process of money social interaction in personal relationships, participate in information and discussions, use media characters and their experiences to solve our own problems (McQuail, 1989). While scientists continue to use traditional tools and typologies to answer questions about media use, we should be ready to expand the theoretical models of uses and gratifications of this time. Contemporary and future models should include concepts such as 
interaction, demassification, hypertextuality, and asynchroneity. Researchers should be willing to explore the interpersonal and qualitative aspects of communication mediated by a more holistic method (Ruggiero, 2000).

In today's society with digital communication and media, gifted students' attitudes towards new media are very important in environments where there is asynchronousness compared to contemporary and future models. This situation has led the uses and gratification theory to come to the fore for this study.

It has been determined that the gifted students use technology very well with the previous studies and literature review (Nugeni, 2001; Barak, 2000). Therefore, researcher's working in a gifted centre and his findings (İşman \& Kara, 2017) lead this study to initiate to determine whether these students, who use technology very well, use social media consciously in the context of new media literacy. A new media literacy for them will be prepared based on curriculum according to the findings of the problems the gifted students using social media because there is no media literacy in gifted centres, Turkey.

Hence, the aim of this study through quantitative research is to determine the social media habits and the aim of social media usages of gifted students through new media literacy. The subaims are as follows:

1. to designate for what purpose they use social media,

2. to specify whether they use new media effectively,

3. to analyse how much time they spend on social media and

4. to determine whether there are significant differences between the variables by considering gender, age and class level variables of social media attitudes through a new media literacy perspective.

\section{Methodology}

In this study, a quantitative research method was used to determine the intentions of social media use and levels of usage of gifted children in the context of new media literacy. Quantitative research is defined as a social research using empirical methods and expressions. An empirical statement reveals what it is like to research extensively in real world research (Cohen, 1980).

In quantitative research, a more positivist world view is dominant. These worldviews, also referred to as the paradigm, are argued to depend on the techniques used in the research and on the perceptions of different world views. Quantitative research methods are research methods dealing with the numbers that can be measured systematically of events and their relations. It is used to answer questions about relationships within measurable variables to explain, predict, and control an event (Leedy, 1993).

Using quantitative methods, researchers define one or more variables they want to use in their study and continue to collect data about these variables. Quantitative methods in the field of information and communication technologies are usually related to computation of results and system analysis with a scientific approach. The aim of the quantitative method is to develop and use models based 
on mathematical approaches, hypotheses, theories about the nature of the phenomenon of information and communication technologies. The quantitative paradigm is considered by researchers as an interdisciplinary framework of science studies with a positivist perspective (Jasanoff \& Markle \& Peterson \& Pinch, 2002; Hackett, 2007).

In quantitative research of this study, validity and reliability procedures were carried out in order to develop a scale designed to measure the attitudes of gifted students towards social media and to fit the five-likert scale model (Otrar and Argın, 2015, quoted from Köklü, 1995).

Survey was applied for 101 gifted students after measurement of reliability and validity. The Pearson Moments Multiplication Correlation Coefficient was calculated for all materials, sub-dimensions, and scale. SPSS 22 (Statistical Package for the Social Sciences) statistical program was used for all validity and reliability analyses. $\mathrm{T}$ test and Anova were used for data analysis.

İzmit Science and Art Centre in Turkey has been selected because of reliability and validity. The fact that the researcher's working in this gifted centre is important in terms of conducting studies such as test-retest and pilot studies. The number of gifted students is relatively less; however the location of the study mentioned is suitable to reach necessary numbers of the students.

\section{The Problem Statement}

The problem statement of the research was defined as follows: What are the aims and attitudes of gifted students to social media in context of new media literacy in Turkey?

\section{Sub Problems}

1. Is there a meaningful difference in answers to questions that measure students' habits of social media use compared to grade level?

2. Is there a meaningful difference in answers to questions that measure students' habits of social media use compared to gender?

3. Is there a meaningful difference in the answers given by students to the questions that measure social media usage habits according to the social media sites?

4. Is there a meaningful difference in the answers given by students to the questions that measure social media usage habits according to the duration of social media use?

5. Is there a meaningful difference in the answers given by students to the questions that measure social media usage habits according to the frequency of social media use? 


\section{Research Model}

This study is quantitative based on empirical research. It focuses on the uses and gratification approach, because it is explored, what the students do in the new media not what the new media does to the students. Validity and reliability procedures were carried out in order to develop a scale designed to measure the attitudes of gifted students towards social media and to fit the five-likert scale model.

Survey was used as data collection technique. A pilot survey was applied to 100 gifted students. In order to determine the stability of the scale in the context of reliability, the test-retest method was carried out with an interval of three weeks. Reliability coefficients were also significant for each sub-dimension $(0.72-0.89 ; \mathrm{p}$ $<.001)$ and the correlation coefficient calculated for the whole scale $(0.83 ; p<.001)$ was found significant. All validity and reliability analysis has been carried out through SPSS 22 (Statistical Package for the Social Sciences) program.

Survey was applied for 101 gifted students after measurement of reliability and validity. All the students answered the survey. The Pearson Moments Multiplication Correlation Coefficient was calculated for all materials, subdimensions, and scale. SPSS 22 (Statistical Package for the Social Sciences) statistical program was used for all validity and reliability analyses. $\mathrm{T}$ test and Anova were used for data analysis.

In this study descriptive survey was utilized to determine the aim and attitudes of gifted students to social media in the axes of new media literacy. In this study; the validity and reliability procedures were performed by using the attitude scales of Otrar and Argin (2015) on social media. Studies are usually carried out in a natural setting, as descriptive or survey studies are required to determine the current situation. An event, individual or an object is tried to be defined in its own context, as it is within its own conditions. There are some techniques used with descriptive research. Survey, interviews and observations are among them. Survey study was applied in the context of descriptive survey model in this study.

\section{Population Group}

The population group consists of all of the gifted students who attend İzmit Science and Art Centre during 2017-2018 academic years.

\section{Sample Group}

Based on random sampling, 101 gifted students between the ages of 6 and 17 who were educated at İzmit Science and Art Centre were selected.

\section{Data Collection Tool}

The 'Social Media Attitude Scale' developed by Otrar and Argin in 2015 was used in the study. The scale consists of five-likert scale. Survey was used as data collection technique. In order to determine the stability of the scale in 
the context of reliability, the test-retest method was performed with a three week search. Reliability coefficients for each subscale and the correlation coefficient calculated for the whole scale were meaningful. All validity and reliability analyses were performed with SPSS 22 (Statistical Package for the Social Sciences) package program.

\section{Data Analysis}

The data obtained from the study were analysed in the SPSS 22 (Statistical Package for Social Sciences) program. In the data analysis obtained, descriptive statistical methods such as percentage, T- test and one way Anova were used.

\section{Assumptions}

Since the researcher works in the gifted centre called Science and Art Centre as a teacher and with preliminary studies, it has been assumed as follows:

1. Gifted students use the social media in a productive way according to their aims and attitudes.

2. Gifted students use the social media consciously according to their needs.

3. The gifted students responded sincerely to the questions.

\section{Limitations}

1. The research is limited to gifted students between the ages of 6-17 who are educated in İzmit Science and Art Centre which is in Kocaeli province in 2017-2018 academic year.

2. The research is limited to the gifted students who are between 6-17 years old and the answers they give to the scales, and the attitude scale for social media usage.

3. The research is limited to 101 randomly selected gifted students in İzmit Science and Art Centre in Kocaeli province.

\section{Findings/Results}

In this part, findings related to the use of social media, internet and new media obtained as a result of the data analysis collected within the scope of the research are included. The survey study was carried out with 101 gifted students having education in İzmit Science and Art Centre. Percentages of the answers given in the survey questions were calculated. Findings were explained using tables as follows:

Table 1. Gender

\begin{tabular}{|c|c|c|c|c|c|}
\hline \multicolumn{2}{|c|}{} & Frequency & Percent & Valid Percent & $\begin{array}{c}\text { Cumulative } \\
\text { Percent }\end{array}$ \\
\hline \multirow{3}{*}{ Valid } & Female & 51 & 50.5 & 50.5 & 50.5 \\
\cline { 2 - 6 } & Male & 50 & 49.5 & 49.5 & 100.0 \\
\cline { 2 - 6 } & Total & 101 & 100.0 & 100.0 & \\
\hline
\end{tabular}


According to Table 1, 50.5\% (51 people) are females and $49.5 \%$ (50 people) are males of total 101 people in the study group when participants, who answered the survey questions, were examined in terms of gender change.

Table 2. Age

\begin{tabular}{|c|c|c|c|c|c|}
\hline \multicolumn{2}{|c|}{} & Frequency & Percent & Valid Percent & $\begin{array}{c}\text { Cumulative } \\
\text { Percent }\end{array}$ \\
\hline \multirow{4}{*}{ Valid } & $6-9$ age & 21 & 20.8 & 20.8 & 20.8 \\
\cline { 2 - 6 } & $10-13$ age & 63 & 62.4 & 62.4 & 83.2 \\
\cline { 2 - 6 } & $14-17$ age & 17 & 16.8 & 16.8 & 100.0 \\
\cline { 2 - 6 } & Total & 101 & 100.0 & 100.0 & \\
\hline
\end{tabular}

When compared to the age between 6 and 17 years old-participants in Table 2 ; it is seen that participants with the age of 6-9 consist of $20.8 \%$ (21 people), $10-13$ consist of $62.4 \%$ (63 people), and $14-17$ consist of $16.8 \%$ (17 people) of total 101 participants in the study group.

Table 3. Grade

\begin{tabular}{|c|c|c|c|c|c|}
\hline \multicolumn{2}{|c|}{} & Frequency & Percent & Valid Percent & $\begin{array}{c}\text { Cumulative } \\
\text { Percent }\end{array}$ \\
\hline \multirow{4}{*}{ Valid } & $2-4$ & 53 & 52.5 & 52.5 & 52.5 \\
\cline { 2 - 6 } & $5-7$ & 44 & 43.6 & 43.6 & 96.0 \\
\cline { 2 - 6 } & $8-10$ & 4 & 400 & 4.0 & 100.0 \\
\cline { 2 - 6 } & Total & 101 & 100.0 & 100.0 & \\
\hline
\end{tabular}

As it is seen in Table 3, participants with the grades between 2-4 are 52.5\% (53 people), 5-7 are 43,6\% (44 people), and 8-10 are 4\% (4 people). 2-4, 5-7 and 8-10 are school grades. The grades have been divided according to the groups in the gifted centre. 2-4 grades are support groups, 5-7 grades are noticing individual ability groups, and 8-10 grades are special skills development program groups.

Table 4. Social Media Usage

\begin{tabular}{|c|c|c|c|c|c|}
\hline \multicolumn{2}{|c|}{} & Frequency & Percent & Valid Percent & $\begin{array}{c}\text { Cumulative } \\
\text { Percent }\end{array}$ \\
\hline \multirow{4}{*}{ Valid } & Facebook & 3 & 3.0 & 3.0 & 3.0 \\
\cline { 2 - 6 } & YouTube & 69 & 68.3 & 68.3 & 71.3 \\
\cline { 2 - 6 } & Instagram & 10 & 9.9 & 9.9 & 81.2 \\
\cline { 2 - 6 } & WhatsApp & 19 & 18.8 & 18.8 & 100.0 \\
\cline { 2 - 6 } & Total & 101 & 100.0 & 100.0 & \\
\hline
\end{tabular}

According to Table 4, participants using Facebook consist of 3\% (3 people). Participants using YouTube consist of $68.3 \%$ (69 people). Participants using Instagram consist of $9.9 \%$ (10 people). Participants using WhatsApp consist of $18.8 \%$ (19 people). 
Table 5. Internet Usage

\begin{tabular}{|c|c|c|c|c|c|}
\hline & & Frequency & Percent & Valid Percent & $\begin{array}{c}\text { Cumulative } \\
\text { Percent }\end{array}$ \\
\hline \multirow{6}{*}{ Valid } & Everyday & 52 & 51.5 & 51.5 & 51.5 \\
\hline & 1-2 days in a week & 20 & 19.8 & 19.8 & 71.3 \\
\hline & $3-5$ days in a week & 23 & 22.8 & 22.8 & 94.1 \\
\hline & $\begin{array}{l}1-2 \text { days in a } \\
\text { month }\end{array}$ & 4 & 4.0 & 4.0 & 98.0 \\
\hline & $\begin{array}{l}3-5 \text { days in a } \\
\text { month }\end{array}$ & 2 & 2.0 & 2.0 & 100.0 \\
\hline & Total & 101 & 100.0 & 100.0 & \\
\hline
\end{tabular}

As it is seen in Table 5, those of using internet everyday are 51\% (51 people), those of using internet 1-2 days in a week are 19.8\% (20 people), those of using internet 3-5 days in a week are $22.8 \%$ (23 people), those of using internet 1-2 days in a month are 4\% (4 people), and those of using internet 3-5 days in a month consist of $2 \%$ ( 2 people).

Table 6. New Media Usage

\begin{tabular}{|c|c|c|c|c|c|}
\hline \multicolumn{2}{|c|}{} & Frequency & Percent & Valid Percent & $\begin{array}{c}\text { Cumulative } \\
\text { Percent }\end{array}$ \\
\hline \multirow{4}{*}{ Valid } & Once more a day & 35 & 34.7 & 34.7 & 34.7 \\
\cline { 2 - 6 } & Once a day & 20 & 19.8 & 19.8 & 54.5 \\
\cline { 2 - 6 } & Once more a week & 19 & 18.8 & 18.8 & 73.3 \\
\cline { 2 - 6 } & Once a week & 4 & 4.0 & 4,0 & 77.2 \\
\cline { 2 - 6 } & A few times a month & 23 & 22.8 & 22.8 & 100,0 \\
\cline { 2 - 6 } & Total & 101 & 100.0 & 100.0 & \\
\hline
\end{tabular}

According to Table 6 , those of using new media once more a day are $34.7 \%$ (35 people), those of using new media once a day are $19.8 \%$ (20 people), those of using new media once more a week are $18.8 \%$ (19 people), those of using new media once a week are $4 \%$ (4 people), and those of using new media a few times a month consist of $22.8 \%$ ( 23 people).

According to Table 7 , the calculated $\alpha$ values $(\alpha: 0.015<\alpha: 0.05),(\alpha: 0.036$ $<\alpha: 0.05),(\alpha: 0.002<\alpha: 0.05)$, and $(\alpha: 0.018<\alpha: 0.05)$ are smaller than 0.05 . There are meaningful differences for gender of the questions: 'I use social media for sharing academic information (homework, projects, etc.)', 'I use social media to exchange ideas on topics of interest for me', 'I use social media to find solutions to everyday problems', and 'I like sharing text, video, music, etc. on social media sites.' There is no significant difference for the other survey questions according to the gender because the calculated $\alpha$ value is bigger than $\alpha: 0.05$. 
Table 7. Gender for T-Test

\begin{tabular}{|c|c|c|c|c|c|c|c|c|c|c|}
\hline \multicolumn{11}{|c|}{ Independent Samples Test } \\
\hline & & \multicolumn{2}{|c|}{$\begin{array}{c}\text { Levene's Test for } \\
\text { Equality of Variances }\end{array}$} & \multicolumn{7}{|c|}{ t-test for Equality of Means } \\
\hline & & \multirow[t]{2}{*}{$\mathrm{F}$} & \multirow[t]{2}{*}{ Sig. } & \multirow[t]{2}{*}{$\mathrm{t}$} & \multirow[t]{2}{*}{ df } & \multirow[t]{2}{*}{$\begin{array}{l}\text { Sig. (2- } \\
\text { tailed) }\end{array}$} & \multirow[t]{2}{*}{$\begin{array}{c}\text { Mean } \\
\text { Difference }\end{array}$} & \multirow[t]{2}{*}{$\begin{array}{l}\text { Std. Error } \\
\text { Difference }\end{array}$} & \multicolumn{2}{|c|}{$\begin{array}{l}95 \% \text { Confidence } \\
\text { Interval of the } \\
\text { Difference }\end{array}$} \\
\hline & & & & & & & & & Lower & Upper \\
\hline \multirow{2}{*}{$\begin{array}{l}\text { I use social media for } \\
\text { sharing academic } \\
\text { information } \\
\text { (homework, projects, } \\
\text { etc.). }\end{array}$} & $\begin{array}{c}\text { Equal variances } \\
\text { assumed }\end{array}$ & 1.672 & 0.199 & 2.476 & 99 & 0.015 & 0.669 & 0.270 & 0.133 & 1.206 \\
\hline & $\begin{array}{c}\text { Equal variances } \\
\text { not assumed }\end{array}$ & & & 2.472 & 96.276 & 0.015 & 0.669 & 0.271 & 0.132 & 1.207 \\
\hline \multirow{2}{*}{$\begin{array}{l}\text { I use social media to } \\
\text { exchange ideas on } \\
\text { topics of interest for } \\
\text { me. }\end{array}$} & $\begin{array}{c}\text { Equal variances } \\
\text { assumed }\end{array}$ & .013 & 0.910 & 2.122 & 99 & 0.036 & 0.589 & 0.278 & 0.038 & 1.140 \\
\hline & $\begin{array}{c}\text { Equal variances } \\
\text { not assumed }\end{array}$ & & & 2.122 & 98.780 & 0.036 & 0.589 & 0.278 & 0.038 & 1.140 \\
\hline \multirow{2}{*}{$\begin{array}{l}\text { I use social media to } \\
\text { find solutions to } \\
\text { everyday problems. }\end{array}$} & $\begin{array}{c}\text { Equal variances } \\
\text { assumed }\end{array}$ & 1.204 & 0.275 & 3.238 & 99 & 0.002 & 0.816 & 0.252 & 0.316 & 1.317 \\
\hline & $\begin{array}{c}\text { Equal variances } \\
\text { not } \text { assumed }\end{array}$ & & & 3.236 & 98.354 & 0.002 & 0.816 & 0.252 & 0.316 & 1.317 \\
\hline \multirow{2}{*}{$\begin{array}{l}\text { I like sharing text, } \\
\text { video, music, etc. on } \\
\text { social media sites. }\end{array}$} & $\begin{array}{c}\text { Equal variances } \\
\text { assumed }\end{array}$ & 1.057 & 0.306 & 2.407 & 99 & 0.018 & 0.658 & 0.273 & 0.116 & 1.201 \\
\hline & $\begin{array}{c}\text { Equal variances } \\
\text { not } \text { assumed }\end{array}$ & & & 2.410 & 98.224 & 0.018 & 0.658 & 0.273 & 0.116 & 1.200 \\
\hline
\end{tabular}


The number of arithmetic mean for the question 'I use social media for sharing academic information (homework, projects, etc.)' of females is 3.53 while males is 2.86. It shows that females use social media for sharing academic information more than males. The number of arithmetic mean for the question 'I use social media to exchange ideas on topics of interest for me' of females is 3.55 while males is 2.96 . It shows that females use social media to exchange ideas on topics for themselves more than males. The number of arithmetic mean for the question 'I use social media to find solutions to everyday problems.' of females is 3.18 while males is 2.36 . It shows that females use social media to find solutions to everyday problems more than males. The number of arithmetic mean for the question 'I like sharing text, video, music, etc. on social media sites' of females is 3.10 while males is 2.44 . It shows that females like sharing text, video, music etc. on social media sites more than males.

Table 8. Anova Test for Age

\begin{tabular}{|c|c|c|c|c|c|c|}
\hline & & $\begin{array}{l}\text { Sum of } \\
\text { Squares }\end{array}$ & df & Mean Square & $\mathrm{F}$ & Sig. \\
\hline I use social & $\begin{array}{l}\text { Between } \\
\text { Groups }\end{array}$ & 13.819 & 2 & 6.909 & 3.673 & 0.029 \\
\hline $\begin{array}{l}\text { media to express } \\
\text { myself. }\end{array}$ & $\begin{array}{l}\text { Within } \\
\text { Groups }\end{array}$ & 184.340 & 98 & 1.881 & & \\
\hline & Total & 198.158 & 100 & & & \\
\hline $\begin{array}{l}\text { I use social } \\
\text { media to get }\end{array}$ & $\begin{array}{l}\text { Between } \\
\text { Groups }\end{array}$ & 16.774 & 2 & 8.387 & 4.268 & 0.017 \\
\hline $\begin{array}{l}\text { away from the } \\
\text { things that make }\end{array}$ & $\begin{array}{l}\text { Within } \\
\text { Groups }\end{array}$ & 192.592 & 98 & 1.965 & & \\
\hline $\begin{array}{l}\text { me unnappy } \\
\text { when I'm } \\
\text { unhappy }\end{array}$ & Total & 209.366 & 100 & & & \\
\hline $\begin{array}{l}\text { I like sharing } \\
\text { conversations I }\end{array}$ & $\begin{array}{l}\text { Between } \\
\text { Groups }\end{array}$ & 15.630 & 2 & 7.815 & 4.046 & 0.020 \\
\hline $\begin{array}{l}\text { see on social } \\
\text { media sites with }\end{array}$ & $\begin{array}{l}\text { Within } \\
\text { Groups }\end{array}$ & 189.281 & 98 & 1.931 & & \\
\hline my friends. & Total & 204.911 & 100 & & & \\
\hline I'm happy to & $\begin{array}{l}\text { Between } \\
\text { Groups }\end{array}$ & 13.441 & 2 & 6.720 & 3.432 & 0.036 \\
\hline comment on the & $\begin{array}{l}\text { Within } \\
\text { Groups }\end{array}$ & 191.886 & 98 & 1.958 & & \\
\hline & Total & 205.327 & 100 & & & \\
\hline $\begin{array}{l}\text { I think I can reach } \\
\text { people who have }\end{array}$ & $\begin{array}{l}\text { Between } \\
\text { Groups }\end{array}$ & 15.322 & 2 & 7.661 & 3.601 & 0.031 \\
\hline $\begin{array}{l}\text { common interests } \\
\text { and goals through }\end{array}$ & $\begin{array}{l}\text { Within } \\
\text { Groups }\end{array}$ & 208.519 & 98 & 2.128 & & \\
\hline social media sites. & Total & 223.842 & 100 & & & \\
\hline $\begin{array}{l}\text { I can't spend } \\
\text { enough time with }\end{array}$ & $\begin{array}{l}\text { Between } \\
\text { Groups }\end{array}$ & 15.145 & 2 & 7.572 & 4.913 & 0.009 \\
\hline $\begin{array}{l}\text { my friends } \\
\text { because of social }\end{array}$ & $\begin{array}{l}\text { Within } \\
\text { Groups }\end{array}$ & 151.053 & 98 & 1.541 & & \\
\hline media sites. & Total & 166.198 & 100 & & & \\
\hline
\end{tabular}


According to Table 8, the calculated $\alpha$ values $(\alpha: 0.029<\alpha: 0.05), \alpha: 0.017<$ $\alpha: 0.05), \alpha: 0.020<\alpha: 0.05), \alpha: 0.036<\alpha: 0.05), \alpha: 0.031<\alpha: 0.05)$, and $\alpha: 0.009<$ $\alpha: 0.05)$ are smaller than 0.05 . There are meaningful differences with the question 'I use social media to express myself' for ages 10-13 when compared to 14-17; the question 'I use social media to get away from the things that make me unhappy when I'm unhappy' for ages 6-9 compared to 14-17; the question 'I like sharing conversations I see on social media sites with my friends' for ages 6-9 compared to 14-17; the question 'I'm happy to comment on the content on social media sites' for ages 6-9 compared to 14-17; the question 'I think I can reach people who have common interests and goals through social media sites' for ages 6-9 compared to 14-17; and the question 'I can't spend enough time with my friends because of social media sites' for ages 6-9 compared to 10-13 and 14-17 years old.

Table 9. Anova Test for Grade

\begin{tabular}{|c|c|c|c|c|c|c|}
\hline & & $\begin{array}{c}\text { Sum of } \\
\text { Squares }\end{array}$ & $\mathrm{df}$ & Mean Square & $\mathrm{F}$ & Sig. \\
\hline \multirow{3}{*}{$\begin{array}{l}\text { I'm happy to } \\
\text { comment on the } \\
\text { content on social } \\
\text { media sites. }\end{array}$} & $\begin{array}{l}\text { Between } \\
\text { Groups }\end{array}$ & 15.604 & 2 & 7.802 & 4.030 & 0.021 \\
\hline & $\begin{array}{l}\text { Within } \\
\text { Groups }\end{array}$ & 189.723 & 98 & 1.936 & & \\
\hline & Total & 205.327 & 100 & & & \\
\hline \multirow{3}{*}{$\begin{array}{l}\text { I can't spend } \\
\text { enough time witl } \\
\text { my family } \\
\text { because of social } \\
\text { networking sites. }\end{array}$} & $\begin{array}{l}\text { Between } \\
\text { Groups }\end{array}$ & 12.739 & 2 & 6.370 & 3.354 & 0.039 \\
\hline & $\begin{array}{l}\text { Within } \\
\text { Groups }\end{array}$ & 186.132 & 98 & 1.899 & & \\
\hline & Total & 198.871 & 100 & & & \\
\hline \multirow{3}{*}{$\begin{array}{l}\text { I think I can } \\
\text { reach people who } \\
\text { have common } \\
\text { interests and } \\
\text { goals through } \\
\text { social media } \\
\text { sites. }\end{array}$} & $\begin{array}{l}\text { Between } \\
\text { Groups }\end{array}$ & 14.661 & 2 & 7.331 & 3.434 & 0.036 \\
\hline & $\begin{array}{l}\text { Within } \\
\text { Groups } \\
\end{array}$ & 209.180 & 98 & 2.134 & & \\
\hline & Total & 223.842 & 100 & & & \\
\hline
\end{tabular}

According to Table 9, the calculated $\alpha$ values $(\alpha: 0.021<\alpha: 0.05),(\alpha: 0.039<$ $\alpha: 0.05)$, and $(\alpha: 0.036<\alpha: 0.05)$ are smaller than 0.05 . There are meaningful differences with the question 'I'm happy to comment on the content on social media sites' for grade 2-4 when compared to 8-10; the question 'I can't spend enough time with my family because of social networking sites' for grade 5-7 compared to 8-10; and the question 'I think I can reach people who have common interests and goals through social media sites’ for grade 2-4 compared to 8-10. 
Table 10. Anova Test for Social Media Sites

\begin{tabular}{|c|c|c|c|c|c|}
\hline & $\begin{array}{l}\text { Sum of } \\
\text { Squares }\end{array}$ & df & Mean Square & $\mathrm{F}$ & Sig. \\
\hline \begin{tabular}{|l|l|} 
I use social & Between \\
media to follow & Groups \\
\end{tabular} & 18.704 & 3 & 6.235 & 3.232 & 0.026 \\
\hline \begin{tabular}{l|l} 
people and & Within \\
organizations I & Groups
\end{tabular} & 187.098 & 97 & 1.929 & & \\
\hline Total & 205.802 & 100 & & & \\
\hline \begin{tabular}{l|l} 
I like sharing & Between \\
conversations I & Groups
\end{tabular} & 18.601 & 3 & 6.200 & 3.228 & 0.026 \\
\hline \begin{tabular}{l|l} 
see on social & Within \\
media sites with & Groups
\end{tabular} & 186.310 & 97 & 1.921 & & \\
\hline my friends. & 204.911 & 100 & & & \\
\hline
\end{tabular}

According to Table 10 , the calculated two $\alpha$ values $(\alpha: 0.026<\alpha: 0.05)$ are smaller than 0.05 . There is a meaningful difference of the question 'I use social media to follow people and organizations I like' between the social media users of Facebook and Instagram. There is also a meaningful difference of the question 'I like sharing conversations I see on social media sites with my friends' between the social media users of Facebook and Instagram. There aren't meaningful differences for the other social media users because $\alpha$ values are bigger than 0.05 .

Table 11. Anova Test for Duration of Social Media Usage

\begin{tabular}{|c|c|c|c|c|c|c|}
\hline & & $\begin{array}{l}\text { Sum of } \\
\text { Squares }\end{array}$ & $\mathrm{df}$ & Mean Square & $\mathrm{F}$ & Sig. \\
\hline & $\begin{array}{l}\text { Between } \\
\text { Groups }\end{array}$ & 18.611 & 4 & 4.653 & 2.488 & 0.048 \\
\hline $\begin{array}{l}\text { I use social media } \\
\text { to express myself. }\end{array}$ & $\begin{array}{l}\text { Within } \\
\text { Groups }\end{array}$ & 179.547 & 96 & 1.870 & & \\
\hline & Total & 198.158 & 100 & & & \\
\hline I use social media & $\begin{array}{l}\text { Between } \\
\text { Groups }\end{array}$ & 23.502 & 4 & 5.875 & 3.094 & 0.019 \\
\hline and organizations I & $\begin{array}{l}\text { Within } \\
\text { Groups }\end{array}$ & 182.300 & 96 & 1.899 & & \\
\hline & Total & 205.802 & 100 & & & \\
\hline $\begin{array}{l}\text { I like sharing } \\
\text { conversations I see }\end{array}$ & $\begin{array}{l}\text { Between } \\
\text { Groups }\end{array}$ & 25.962 & 4 & 6.491 & 3.482 & 0.011 \\
\hline $\begin{array}{l}\text { on social media } \\
\text { sites with my }\end{array}$ & $\begin{array}{l}\text { Within } \\
\text { Groups }\end{array}$ & 178.949 & 96 & 1.864 & & \\
\hline friends. & Total & 204.911 & 100 & & & \\
\hline It makes me happy & $\begin{array}{l}\text { Between } \\
\text { Groups }\end{array}$ & 20.551 & 4 & 5.138 & 2.473 & 0.049 \\
\hline comment on what I & $\begin{array}{l}\text { Within } \\
\text { Groups }\end{array}$ & 199.410 & 96 & 2.077 & & \\
\hline & Total & 219.960 & 100 & & & \\
\hline
\end{tabular}

According to Table 11, the calculated $\alpha$ values $(\alpha: 0.048<\alpha: 0.05),(\alpha: 0.019<$ $\alpha: 0.05),(\alpha: 0.011<\alpha: 0.05)$, and $(\alpha: 0.049<\alpha: 0.05)$ are smaller than 0.05 . There are 
meaningful differences for internet users of the question 'I use social media to express myself' as duration 3-5 days a month compared to 1-2 days a month; the question 'I use social media to follow people and organizations I like' as duration everyday compared to 3-5 days a month; the question 'I like sharing conversations I see on social media sites with my friends' as duration everyday compared to 1-2 days a month; the question 'It makes me happy when my friends comment on what I share' as duration 3-5 days a week compared to 1-2 days a month and 3-5 days a month.

Table 12. Anova Test for Frequency of Social Media Usage

\begin{tabular}{|c|c|c|c|c|c|c|}
\hline & & $\begin{array}{l}\text { Sum of } \\
\text { Squares }\end{array}$ & df & Mean Square & $\mathrm{F}$ & Sig. \\
\hline \multirow{3}{*}{$\begin{array}{l}\text { I use social media } \\
\text { for sharing music. }\end{array}$} & $\begin{array}{l}\text { Between } \\
\text { Groups }\end{array}$ & 18.125 & 4 & 4.531 & 3.043 & 0.021 \\
\hline & $\begin{array}{l}\text { Within } \\
\text { Groups } \\
\end{array}$ & 142.964 & 96 & 1.489 & & \\
\hline & Total & 161.089 & 100 & & & \\
\hline \multirow{3}{*}{$\begin{array}{l}\text { I use social media to } \\
\text { express myself. }\end{array}$} & $\begin{array}{l}\text { Between } \\
\text { Groups }\end{array}$ & 21.208 & 4 & 5.302 & 2.877 & 0.027 \\
\hline & $\begin{array}{l}\text { Within } \\
\text { Groups }\end{array}$ & 176.950 & 96 & 1.843 & & \\
\hline & Total & 198.158 & 100 & & & \\
\hline \multirow{3}{*}{$\begin{array}{l}\text { I use social media to } \\
\text { contribute my } \\
\text { personal } \\
\text { development. }\end{array}$} & $\begin{array}{l}\text { Between } \\
\text { Groups }\end{array}$ & 17.658 & 4 & 4.415 & 2.853 & 0.028 \\
\hline & $\begin{array}{l}\text { Within } \\
\text { Groups }\end{array}$ & 148.560 & 96 & 1.547 & & \\
\hline & Total & 166.218 & 100 & & & \\
\hline \multirow{3}{*}{$\begin{array}{l}\text { I use social media to } \\
\text { follow people and } \\
\text { organizations I like. }\end{array}$} & $\begin{array}{l}\text { Between } \\
\text { Groups }\end{array}$ & 24.473 & 4 & 6.118 & 3.239 & 0.015 \\
\hline & $\begin{array}{l}\text { Within } \\
\text { Groups } \\
\end{array}$ & 181.329 & 96 & 1.889 & & \\
\hline & Total & 205.802 & 100 & & & \\
\hline \multirow{3}{*}{$\begin{array}{l}\text { I want my friends to } \\
\text { notice me through } \\
\text { social media sites. }\end{array}$} & \begin{tabular}{|l|} 
Between \\
Groups
\end{tabular} & 21.098 & 4 & 5.274 & 3.431 & 0.011 \\
\hline & $\begin{array}{l}\text { Within } \\
\text { Groups }\end{array}$ & 147.595 & 96 & 1.537 & & \\
\hline & Total & 168.693 & 100 & & & \\
\hline \multirow{3}{*}{$\begin{array}{l}\text { I like sharing } \\
\text { conversations I see } \\
\text { on social media sites } \\
\text { with my friends. }\end{array}$} & $\begin{array}{l}\text { Between } \\
\text { Groups }\end{array}$ & 37.250 & 4 & 9.312 & 5.332 & 0.001 \\
\hline & $\begin{array}{l}\text { Within } \\
\text { Groups }\end{array}$ & 167.661 & 96 & 1.746 & & \\
\hline & Total & 204.911 & 100 & & & \\
\hline \multirow{3}{*}{$\begin{array}{l}\text { I'm happy to } \\
\text { comment on the } \\
\text { content on social } \\
\text { media sites. }\end{array}$} & $\begin{array}{l}\text { Between } \\
\text { Groups }\end{array}$ & 28.447 & 4 & 7.112 & 3.860 & 0.006 \\
\hline & $\begin{array}{l}\text { Within } \\
\text { Groups }\end{array}$ & 176.879 & 96 & 1.842 & & \\
\hline & Total & 205.327 & 100 & & & \\
\hline \multirow{3}{*}{$\begin{array}{l}\text { I like sharing text, } \\
\text { video, music, etc. on } \\
\text { social media sites. }\end{array}$} & \begin{tabular}{|l|} 
Between \\
Groups
\end{tabular} & 22.405 & 4 & 5.601 & 3.066 & 0.020 \\
\hline & $\begin{array}{l}\text { Within } \\
\text { Groups }\end{array}$ & 175.358 & 96 & 1.827 & & \\
\hline & Total & 197.762 & 100 & & & \\
\hline
\end{tabular}




\begin{tabular}{|c|c|c|c|c|c|c|}
\hline \multirow{3}{*}{$\begin{array}{l}\text { I think I got rid of } \\
\text { loneliness thanks to } \\
\text { social media sites. }\end{array}$} & \begin{tabular}{|l} 
Between \\
Groups
\end{tabular} & 31.009 & 4 & 7.752 & 5.207 & 0.001 \\
\hline & $\begin{array}{l}\text { Within } \\
\text { Groups }\end{array}$ & 142.931 & 96 & 1.489 & & \\
\hline & Total & 173.941 & 100 & & & \\
\hline \multirow{3}{*}{$\begin{array}{l}\text { I think I can reach } \\
\text { people who have } \\
\text { common interests } \\
\text { and goals through } \\
\text { social media sites. }\end{array}$} & $\begin{array}{l}\text { Between } \\
\text { Groups }\end{array}$ & 28.414 & 4 & 7.103 & 3.489 & 0.010 \\
\hline & $\begin{array}{l}\text { Within } \\
\text { Groups }\end{array}$ & 195.428 & 96 & 2.036 & & \\
\hline & Total & 223.842 & 100 & & & \\
\hline \multirow{3}{*}{$\begin{array}{l}\text { I am happy to hear } \\
\text { about the events } \\
\text { organized by social } \\
\text { media sites. }\end{array}$} & $\begin{array}{l}\text { Between } \\
\text { Groups }\end{array}$ & 18.567 & 4 & 4.642 & 3.083 & 0.020 \\
\hline & $\begin{array}{l}\text { Within } \\
\text { Groups }\end{array}$ & 144.522 & 96 & 1.505 & & \\
\hline & Total & 163.089 & 100 & & & \\
\hline \multirow{3}{*}{$\begin{array}{l}\text { It makes me happy } \\
\text { when my friends } \\
\text { comment on what I } \\
\text { share. }\end{array}$} & $\begin{array}{l}\text { Between } \\
\text { Groups }\end{array}$ & 22.408 & 4 & 5.602 & 2.722 & 0.034 \\
\hline & $\begin{array}{l}\text { Within } \\
\text { Groups }\end{array}$ & 197.552 & 96 & 2.058 & & \\
\hline & Total & 219.960 & 100 & & & \\
\hline
\end{tabular}

According to Table 12, the calculated $\alpha$ values $(\alpha: 0.021<\alpha: 0.05),(\alpha: 0.027<$ $\alpha: 0.05),(\alpha: 0.028<\alpha: 0.05),(\alpha: 0.015<\alpha: 0.05),(\alpha: 0.011<\alpha: 0.05),(\alpha: 0.001<$ $\alpha: 0,05),(\alpha: 0,006<\alpha: 0.05),(\alpha: 0,020<\alpha: 0.05),(\alpha: 0.001<\alpha: 0.05),(\alpha: 0.010<$ $\alpha: 0.05),(\alpha: 0.020<\alpha: 0.05)$, and $(\alpha: 0.034<\alpha: 0.05)$ are smaller than 0.05 . There are meaningful differences for new media users of the question 'I use social media for sharing music' as frequency once a day compared to once more a week; the question 'I use social media to express myself' as frequency once more a day compared to once a week; the question 'I use social media to contribute my personal development' as frequency once a day and once a week compared to $a$ few times a month; the question 'I use social media to follow people and organizations I like' as frequency' as frequency once more a day compared to a few times a month; the question 'I want my friends to notice me through social media sites' as frequency once a day compared to a few times a month.; the question 'I like sharing conversations I see on social media sites with my friends' as frequency once more a day compared to a few times a month; the question 'I'm happy to comment on the content on social media sites' as frequency once more a day compared to a few times a month; the question 'I like sharing text, video, music, etc. on social media sites' as frequency once more a day compared to a few times a month; the question 'I think I got rid of loneliness thanks to social media sites' as frequency once more a day compared to a few times a month; the question 'I think I can reach people who have common interests and goals through social media sites' as frequency once more a day compared to a few times a month; the question 'I am happy to hear about the events organized by social media sites' as frequency once a day compared to a few times a month; the question 'It makes me happy when my friends comment on what I share' as frequency once a week compared to a few times a month.

In this study a quantitative approach has been used. In quantitative research, survey questions have been answered by total 101 participants in Kocaeli, Turkey. 
They are 51 females and 50 males. The participants' age ranges are 6-17. The participants with the age of 6-9 consist of $20.8 \%$ (21 people), 10-13 consist of $62.4 \%$ (63 people), and $14-17$ consist of $16.8 \%$ (17 people) in the study group. The participants with the grades $2-4$ are $52.5 \%$ (53 people), 5-7 are $43.6 \%$ (44 people), and $8-10$ are $4 \%$ (4 people). $68.3 \%$ (69 people) use YouTube while 3\% (3 people) use Facebook, 9.9\% (10 people) use Instagram and 18.8\% (19 people) use WhatsApp. According to the results, most of the participants prefer using YouTube.

The participants who use internet every day are $51 \%$ (51 people), 1-2 days in a week are $19.8 \%$ (20 people), 3-5 days in a week are $22.8 \%$ (23 people), 1-2 days in a month are $4 \%$ (4 people), and 3-5 days in a month are $2 \%$ ( 2 people). Most of the participants use internet every day. The participants who use new media once more a day are $34.7 \%$ (35 people) while those of using new media once a day are $19.8 \%$ (20 people), once more a week are $18.8 \%$ (19 people), once a week are $4 \%$ (4 people), and a few times a month are $22.8 \%$ (23 people). Most of the participants use new media once more a day.

According to the result of 'Gender for T-Test', females use social media to share academic information; to exchange ideas on topics for themselves; to find solutions to everyday problems; to share text, video, music etc. on social media sites more than males. As for the tables, there are meaningful differences in the answers to questions that measure students' habits of social media use compared to grade level; to gender; to the social media sites; to the duration of social media use; and in the answers given by students to the questions that measure social media usage habits according to the frequency of social media use.

\section{Conclusions}

This study contributes to digital learning practices of Science and Art Centres dealing with gifted students' concerns on social media. The social media usage of gifted students is determined within the scope of new media literacy, and it sheds light on the importance of new media literacy in future studies. This can be provided through new media literacy activities at gifted centres.

Gifted students use social media at schools, Science and Art Centres and home consciously but indiscriminately. The information about social media outlet is important to determine which social media outlet is useful for gifted students in the context of new media literacy. The times of new media usage is also important to determine whether their new media usage affects their success in the context of new media literacy.

The fact that gifted students will lead the future of the country and that we live in the digital era increases the importance of the new media literacy at Science and Art Centres in Turkey. The new media literacy will bring along multidisciplinary studies with other activities. This will lead to technological integration studies to help develop training applications at Science and Art Centres in the country.

The gifted students could do their homework and obtain special education according to their needs. They also need to be directed correctly in the digital 
media so that they can do better in education. However, Science and Art Centres don't have a new media literacy study. Gifted students need to be better directed in the new media in order to reach the desired level in education.

Apart from İzmit Science and Art Centre, the time processes of gifted students are quite intense. It seems that new media is very advantageous for them in order to be able to evaluate the time efficiently related to the homework and projects in their educational institutions. Therefore, they can do research in a very short time through new media. They take the advantages of getting all kinds of information easily and in a short time. However, when they spend time on social media, they can't use the time efficiently because of their entertainment content. However, it is important that they become aware of this situation or make them aware of it. Such awareness can be achieved through new media literacy.

The potential of gifted student and learning skills should be revealed in a short time with the right guidance in digital environment. Accordingly, Science and Art Centres are required to make efforts on the digital platform to maximize students' skills. New media literacy that can integrate the digital platform into special education can be presented to the Ministry of National Education with this study. In this way, gifted students who will determine the vision of the future will be able to use the digital media channels accurately and effectively within the framework of values education. The impact of using new media for gifted students' academic achievement can be studied through both qualitative and quantitative studies to get necessary information for future research.

\section{References}

Abe, P. and Jordan, N.A. 2013. Integrating social media into the classroom curriculum. About Campus, 18(1), 16-20. doi: https://doi.org/10.1002/abc.21107

Bal, A., Grewal, D., Mills, A. and Ottley, G. 2015. Engaging students with social media. Journal of Marketing Education, 37(3), 190-203. doi: https://doi.org/10.1177/02734 75315593380

MEB 2009. Bilim ve sanat merkezleri yönergesi [Science and Art Centres Directive] Retrieved from http://mevzuat.meb.gov.tr/html/2593_0.html

Biçen, H. and Arnavut, A. 2015. Students' technological device use habits on their social lives. Computers in Human Behavior, 48, 457- 462.

Cohen, L. 1980. Research methods in education, London: Groom Helm Ltd.

Connoly, J.P. 2018. Exploring the factors influencing gifted adolescents' resistance to report experiences of cyberbullying behavior. Toward an Improved Understanding Journal for the Education of the Gifted, 41(2) 136-159.

Cross, T.L. 2004. Technology and the unseen world of gifted students: social emotional needs. Gifted Child Today, 27(4), 1-3.

Freeman, J. 2014. Possible effects of electronic social media on gifted and talented children's intelligence and emotional development. Gifted Education International, 32(2), 165-172.

Gömleksiz, M.N., Kan, A.Ü. and Öner, Ü. 2012. Üstün zekâlı ve üstün yetenekli öğrencilerin medya okuryazarlı̆̆ına ilişkin görüşleri (Elazığ Bilim ve Sanat Merkezi Örneği) [Gifted and Talented Students' Perceptions of Media Literacy (Case of Elazığ Science and Art Centre)] Pegem Eğitim ve Öğretim Dergisi [Pegem Journal of Education and Instruction], 2(4), 41-54. 
Grewal, D., Roggeveen, A.L. and Shankaranarayanan, G. 2015. Marketing-Its integration: Developing next-generation managers. In V. L. Crittenden, K. Esper, N. Karst, \& R. Slegers (Eds.), Evolving entrepreneurial education: Innovation in the Babson classroom. Bingley, England: Emerald.

Güzel, M. and Kara, N. 2017. Özel yetenekli öğrencilerin yeni medya kullanımları ve akademik başarılarına etkisi [The new media use of gifted students and its impact on academic achievement] Gençlik Araşstrmaları Dergisi [Journal of Youth Researches], $5(12), 115$.

Hackett, E.J. ed. 2007. Handbook of science and technology studies. Cambridge, MA: MIT Press.

İşman, A. and Kara, N. 2017. Türkiye'deki üstün zekalı öğrencilerin yeni medyaya karşı tutumları ve yeni medya kullanım düzeyleri [Attitudes towards new media and new media usage levels of gifted students in Turkey]. International Conference on New Horizons in Education Conference (INTE).

Jasanoff, S., Markle, G. E., Peterson, J.C. and Pinch, T.J. 2002. Handbook of science and technology studies. Thousand Oaks, CA: Sage.

Kara, N. 2019. Impact of digital media on gifted students' career choices, Journal for the Education of Gifted Young Scientists, 7(2), 99-112. doi: http://dx.doi.org/10.17478/je gys.555339

Köroğlu, İ.Ş. 2015. Üstün yetenekli dijital yerlilerin sosyal medya kullanımları üzerine nicel bir çalışma [Social media usage of gifted digital natives: a quantitative study] Iletisim Kuram ve Araştırma Dergisi [Journal of Communication Theory and Research] 40, 267-290.

Leedy, P.D. 1993. Practical research: planning and design. New Jersey: Prentice-Hall.

Lowther, D.L., Inan, F.A., Ross, S.M. and Strahl, J.D. 2012. Do one-to-one initiatives bridge the way to 21st century knowledge and skills? Journal of Educational Computing Research, 46(1), 1-30. doi: https://doi.org/10.2190/EC.46.1.a

Marland, S.P. Jr. 1972. Education of the gifted and talented: Report to the Congress Of The United States by the U.S. Commissioner Of Education And Background Papers Submitted to the U.S. Office of Education, 2 Vols. Washington, Dc: U.S. Government Printing Office. (Government Documents Y4.L 11/2:G36).

McQuail D. 1989. Mass communication theory, Second Edition, Sage Publications, Great Britain.

Otrar, M. and Argın S. 2015. Öğrencilerin sosyal medyaya ilişkin tutumlarını belirlemeye yönelik bir ölçek geliştirme çalışması [A scale development study to determine the attitude of students' towards social media], Ĕ̈itim ve Ögretim Araştırmaları Dergisi [Journal of Research in Education and Teaching] 4(1), 391-403.

Özcan, D. and Bicen, H. 2016. Giftedness and technology. Procedia Computer Science, 102, 630-634. doi: https://doi.org/10.1016/j.procs.2016.09.453

Ruggiero, E. 2000. Uses and gratifications theory in the 21st Century, Mass Communication \& Society, 3(1).

Siegle, D. and Foster, T. 2001. Laptop computers and multimedia and presentation software: their effects on student achievement in anatomy and physiology. Journal of Research on Technology in Education, 34 (1), 29-37. Retrieved from http://search. ebscohost.com/login.aspx?direct=true\&db=edsbl\&AN=RN109397003\&lang=tr\&site -live\&scope=site doi: $10.1080 / 15391523.2001 .10782331$ 